\title{
Web 2.0 Araçları Kullanımı Yetkinliği Ölçeği Geliştirme Çalışması*
}

\section{Türkan ÇELİK ${ }^{1}$}

- Geliş Tarihi: 06.03.2020 • Kabul Tarihi: 03.11.2020 • Çevrimiçi Yayın Tarihi: 03.11.2020

\section{$\ddot{O} z$}

Bu çalışmada öğretmen ve öğretmen adaylarının Web 2. 0 araçları kullanım yetkinliğini tespit etmek için Likert tipi bir ölçme aracını geliştirmek amaçlanmıştır. Bu amaç doğrultusunda literatür taraması yapılarak 50 maddelik bir deneme formu hazırlanmıştır. Form uzman görüşüne sunulup gerekli düzeltmeler yapıldıktan sonra 2019-2020 öğretim yılında 409 öğretmen ve öğretmen adayına uygulanmıştır. Araştırma örnekleminden elde edilen veriler SPSS (Statistical Package for the Social Sciences) ve Lisrel paket programları kullanılarak açımlayıcı faktör analizi (AFA), doğrulayıcı faktör analizi, madde analizleri, madde toplam korelasyonu ve Cronbach Alpha testleri gerçekleştirilmiştir. DFA aşaması için Gaziantep Üniversitesi, Pamukkale Üniversitesi ve Trabzon Üniversite'nde öğrenim gören 338 farklı branştan öğretmen ve öğretmen adayına ölçeğin AFA süreci sonundaki form uygulanmıştır. Geçerlik ve güvenirlik analizleri sonrasında 50 madde olarak hazırlanan ölçeğin 39 madde ve tek boyutlu yapısı ile geçerli ve güvenilir bir ölçek olduğu bulguları elde edilmiştir.

Anahtar sözcükler: Web 2. 0 araçları, ölçek geliştirme, öğretmen adayları, Web 2. 0 kullanım yetkinliği.

Atıf:

Çelik, T. (2021). Web 2.0 araçları kullanımı yetkinliği ölçeği geliştirme çalışması. Pamukkale Üniversitesi Eğitim Fakültesi Dergisi, 51, 449-478. doi:10.9779.pauefd.700181

\footnotetext{
${ }^{1}$ Dr. Öğrt. Üyesi, Kilis 7 Aralık Üniversitesi, Eğitim Fakültesi, Türkçe ve Sosyal Bilimler Eğitimi Bölümü, Sosyal Bilgiler Eğitimi Anabilim Dalı, Kilis, Türkiye, turkancelik@,kilis.edu.tr, ORCID ID: 0000-0001-8380-9419.
} 


\section{Giriș}

Günümüzde yeni teknolojiler her alanda olduğu gibi eğitim ortamlarında da yaygın bir şekilde kullanılmaya başlanmıştır. Öyle ki yeni teknolojilerle bilgi, dar ve kısıtlı alanlardan sıyrılarak her ortama ve herkese kolaylıkla sunulabilmektedir. Hatta kişiler artık bilginin sadece tüketicisi değil, sanal ortamlarda üreticisi pozisyonlarına geçme imkanına da sahip olmaktadır (Çelik, 2019; Telli Yamato, 2014). Nitekim internet teknolojilerindeki hızlı gelişmelerle birlikte oluşan Web 2.0 araçları interaktif öğrenme imkanları sunarak, zamandan ve mekândan bağımsız öğrenme ortamları ve içerikleri tasarlanmasına imkân tanımaktadir.

Eğitim ortamlarında kullanımı gittikçe yaygınlaşmaya başlayan Web 2.0 araçları ikinci nesil web ortamı olmakla bilinmekte olup (Chiou, 2011) kişilerin eş zamanlı etkileşerek iş birliği içinde bilgi, içerik vb. üretmesine ve paylaşmasına imkân tanımaktadır (Hulburt, 2008; Hung ve Yuen, 2010; McLoughlin ve Lee, 2007; O’Reilly, 2007). Eski zamanlardan beri eğitim ortamlarına eşlik eden teknolojik araçlar önceleri kara tahta, tebeşir, kitap, dergi vb. araçlar iken, günümüzde projeksiyon cihazı, Powerpoint sunuları, akıllı tahta gibi araçlara yeni gelişmelerle birlikte internet ve Web (Web 1.0, Web 2.0, Web 3.0, Web 4. 0) teknolojileri de eklenmiştir. Bu süreçle birlikte öğretmenler Facebook, Blog, Wiki gibi uygulamaların (Chou, 2011) yanı sıra Web 2.0 teknolojileri üzerinde oluşturulmuş farklı araçlar da kullanabilmektedirler. Günümüz öğretmenlerinin birçok derse rahatlıkla uyarlayabileceği Web 2.0 uygulamaları ilgili literatürden (Benzer, 2017; Gününç, 2017; Eşgi ve Kocadağ Ünver, 2018; Kazancı ve Dönmez, 2013; Orhan Göksün ve Aşkım Kurt, 2018; Önal, 2018; Şahin, 2013; Tatlı, 2017) de faydalanılarak Tablo 1'de kategoriler halinde sunulmuştur.

Tablo 1 dikkate alındığında öğrenme süreçlerini daha verimli hale getirecek öğrenciyi aktif kılacak Web 2.0 uygulamaları dikkatleri çekmektedir. Her derste rahatlıkla kullanılabilen bu uygulamalar öğrenciye öğrenme sürecinde aktif yaşantı firsatı da sunabilmektedirler. Öyle ki günümüzde eğitim ortamları öğretmen merkezli bir konumdan öğrenci merkezli bir konuma geçmiştir. Yapılandırmacı anlayış doğrultusunda tasarlanan yeni öğretim ortamlarında bilgi ve iletişim teknolojilerinin önemli araçlarından olan Web 2.0 uygulamaları öğrencinin öğrenme süreçlerinde aktif ve katılımcı rolünün yanında yapılandırmacı anlayışı da desteklemektedir. 
Tablo 1. Öğretmen ĕgitiminde ve MEB'deki derslerle bütünleştirilebilecek dijital uygulamalar

\begin{tabular}{|c|c|}
\hline Kategoriler & WEB 2.0 Uygulamaları \\
\hline Zihin Haritası Uygulamaları & $\begin{array}{l}\text { Wisemapping, Pooppet, SpiderScribe, } \\
\text { Mindmeister, MindMaple Lite, Inspiration 9, } \\
\text { Gocongr, Coggle,Mindomo }\end{array}$ \\
\hline Pano Oluşturma Uygulamaları & $\begin{array}{l}\text { Padlet, Blendspase, Lino it, Wordle, Bubble, } \\
\text { RealtimeBord }\end{array}$ \\
\hline $\begin{array}{l}\text { Poster ve Karikatür Oluşturma } \\
\text { Uygulamaları }\end{array}$ & $\begin{array}{l}\text { Word Art, Canva, Make Beliefs Comix, } \\
\text { Toondoo, Sketch toy, Face Your Manga }\end{array}$ \\
\hline Hikâye ve Kitap Yazma Uygulamaları & $\begin{array}{l}\text { Pixton, Storyjumper, Storyboard That, Storybird, } \\
\text { Wattpad, Joomag. }\end{array}$ \\
\hline $\begin{array}{l}\text { Not Alma ve Blog Oluşturma } \\
\text { Uygulamaları }\end{array}$ & Evernote, Trello, Blogger, Tlumblr, Glogster \\
\hline $\begin{array}{l}\text { Test ve Bulmaca Oluşturma } \\
\text { Uygulamaları }\end{array}$ & $\begin{array}{l}\text { Flippquiz, Puzzlemaker, Kahoot, Plickers, } \\
\text { Quiziz, Socrative, Mentimeter, LearningApss } \\
\text { CrossWordLabs, Triventy. }\end{array}$ \\
\hline Sunum ve Animasyon Uygulamaları & $\begin{array}{l}\text { Prezi, Powtoon, Buncee, Emaze, Vyond, Voki, } \\
\text { Mine-İmator, Scracth. }\end{array}$ \\
\hline $\begin{array}{l}\text { Bilgi Afişi ve İnfografik Hazırlama } \\
\text { Uygulamaları }\end{array}$ & Easelly, Visme, Piktochart, Venngage, Creately \\
\hline $\begin{array}{l}\text { Uzaktan Eğitim ve } \text { Sanal Sınıf } \\
\text { Uygulamaları }\end{array}$ & $\begin{array}{l}\text { Edmodo, Moodle, Classdojo, Remind, Beyaz } \\
\text { Pano, Google Clasroom, Adobe Connect, } \\
\text { Bigbluebutton, EBA. }\end{array}$ \\
\hline $\begin{array}{l}\text { Sanal ve Artırılmış } \quad \text { Gerçeklik } \\
\text { Uygulamaları }\end{array}$ & $\begin{array}{l}\text { Aurasma, Quiver, Morfo, Augmented Reality } \\
\text { (AR), Nearpod, Uzay 4 D, Animal 4D }\end{array}$ \\
\hline $\begin{array}{l}\text { Fotoğraf, Film ve Video Düzenleme ve } \\
\text { Tasarım Uygulamaları }\end{array}$ & $\begin{array}{l}\text { Thinklink, GIMP, Mowi maker, Photostory, } \\
\text { Safeshare, OpenShot, Filmora, Nimbb, Jing, } \\
\text { SmartDraw, Vocaro, Davinci } 15 \text { Beta, } \\
\text { AppInventor }\end{array}$ \\
\hline Sosyal Medya Uygulamaları & $\begin{array}{l}\text { Blog, Wiki, Youtube, Skype, Hangout, } \\
\text { Whatsapp, Facebook, Instagram, WebQuest. }\end{array}$ \\
\hline
\end{tabular}


Dolayısıyla Web 2.0 araçlarının eğitim süreçlerinde uygulanması Vygotsky, Jean Piaget, Jerome Bruner gibi eğitimcilerin yanı sıra probleme dayalı öğrenme, bağlaşık öğretim, dağıtık biliş, bilişsel esneklik teorisi, bilişsel çıraklık, durumlu öğrenme, özdüzenleyici öğrenme gibi eğitim teorileri ile de tutarlılık göstermektedir (Gündüz, 2007). Web 2.0 araçlarının bilgiye erişme, grupla çalışma, sosyal etkileşim ve geri bildirim olanaklarını kolay hale getirmesi onların eğitim ortamlarında kullanımını cazip hale getirmiştir (Alexander, 2006; Elmas ve Geban, 2012; Horzum, 2010; McLoughlin ve Lee, 2007; Thompson, 2007). Literatürden de anlaşıldığı üzere her derse rahatlıkla entegre edilebilen Web 2.0 araçları ile bir dersin içeriği oluşturularak ona uygun öğrenme ortamları sağlanabilmektedir (Rich, 2008). Ayrıca Web 2.0 uygulamalarının derslere entegresi ile aktif ve işbirlikçi öğrenme faaliyetleri (Vaughan, 2010) ve yaratıcı etkinliklerin geliştirilmesi de olanak bulmaktadır (Laru, Naykki ve Jarvela, 2012). Yine literatürdeki farklı çalışmalarda (Elswick ve Lennex, 2017; Tsarev 2017; Elmahdi, Hattami ve Fawzi, 2018; Kutlu Demir, 2018; Dellos, 2015; Graham, 2015; Wang ve Lieberoth, 2016; Zarzycka-Piskorz, 2016) da Web 2.0 araçlarının eğitim ortamlarında kullanımının öğrencinin; derse katılımını, dikkatini çekmesini, süreçten memnun olmasını, eğlenmesini, olumlu bağlılık hissetmesini, davranış değişikliği yaşamasını, problem çözme becerisi geliştirmesini, rekabet etme ve motive olmasını sağlamak gibi birçok açıdan katkı sunduğu görülmektedir.

Çağımızda Web 2. 0 araçları kullanmanın en önemli gereklerinden biri de Aralık 2019'da Çin'in Wuhan şehrinde Covid-19 olarak adlandırılan hastalığın ortaya çıkmasıdır. Dünyada pandemi ilan edilmesine neden olan bu olay, birçok kurumun hizmetlerine dijital ortamda devam etmesine neden olduğu gibi eğitim kurumlarının da apar topar dijital araçlar yardımıyla sanal mecralara taşınmasına neden olmuştur. $\mathrm{Bu}$ durum eğitim süreçlerinde dijitalleşme, uzaktan eğitim, Web kullanımı gibi kavramların hayati önemini ve öğretmenler ile öğrencilerin dijital yetkinliklerini de sorgulamayı yeniden gündeme getirmiştir. Zira pandemi sürecinde eğitimin aksamadan uzaktan dijital kanallarla sağlıklı yürütülmesinin mimarları yine öğretmenler olmuştur. Dolayısıyla dijital ağlara yenilginin ve ihtiyacın en açık örneklerinin yaşandığı bu çağda dijital yetkinliğe sahip öğretmenlere ihtiyacın olduğu ortaya çıkmıştır (Geçgel, Kana ve Eren, 2020). Öğretmenlerin eğitim süreçlerinde Web 2. 0 araçlarının işlevlerini, onları kullanmayı ve en önemlisi de kendi alanlarına entegre edebilecek kabiliyete yani yetkinliğe erişmeleri gerekmektedir. Dolayısıyla hem yüz yüze hem de uzaktan eğitim ortamlarında öğrencilerine verimli olabilmek için öğretmenlerin 
birçok konuda olduğu gibi dijital anlamda da yetkin ve donanımlı olması gerekliliği kendini hissettirmektedir.

\section{Çalışmanın Amacı ve Önemi}

$\mathrm{Bu}$ çalışmanın amacı öğretmen ve öğretmen adaylarının Web 2.0 araçlarıyla içerik geliştirme çalışmalarına yönelik "Web 2.0 Araçları Kullanımı Yetkinliği ÖlçeğiniWAKYÖ” geliştirmektir. Özellikle öğretmenlerin hem yüz yüze ortamlarda hem de uzaktan eğitim süreçlerinde rahatlıkla derslerine entegre kullanabilecekleri Web araçlarını kullanabilmeleri eğitimin kalitesi açısından önem taşımakta olup, öğretmen yetiştirme sürecinde de kullanılmalıdır. Zira öğretmen eğitiminde kullanılan Web 2.0 araçları öğretmenlerin, teknolojik pedagojik ve alan bilgilerini bütünleştirme açısından da olumlu katkılar sunmaktadır (Tatlı, İpek-Akbulut ve Altınışık, 2016). Ancak öğretmenlerin güncel teknolojik araçları kapsamlı ve bilinçli kullanmalarının yolu hizmet öncesi dönemlerde aldıkları eğitimlerden geçmektedir. Öğretmen adaylarına verilen eğitimin ölçülmesinde ve öğretmen adaylarının kendilerini yetkin görüp görmediklerine yönelik bilgilerin doğru ölçme araçlarıyla tespit edilmesi gerekmektedir. Ancak eğitim fakültelerinde verilen eğitimin etkililiğinin ölçülmesinde kullanılabilecek ölçekleri içeren çalışmalar sınırlı olup, söz konusu ölçeklerde çalışılan konular şu şekildedir: Bişirici, Kul, Aksu, Akaslan ve Çelik (2017) Web 2.0 hızlı içerik geliştirme öz-yeterlik inancı belirlemeye yönelik; Kuzu-Demir, ve Akbulut (2017) çevrimiçi sosyal ağların öğretim amaçlı kabul ve kullanımına yönelik; Tekkurşun Demir ve Mutlu Bozkurt (2019) dijital oyun oynama tutumuna yönelik; Çam ve Uysal (2017) mobil uygulamaların eğitsel amaçlı kullanımına yönelik; Öztürk ve Horzum (2011) teknolojik pedagojik içerik bilgisi ölçeği’nin Türkçe'ye uyarlamasına yönelik çalışmalar yapmışlardır. Aynı şekilde literatürde (Horzum ve Aydemir, 2014) Web 2. 0 araçlarının eğitsel kullanım özyeterliliğine ilişkin çalışmalara da rastlanmıştır. Geliştirilen ölçme araçlarına bakıldığında Web 2.0 araçlarının öğretmen eğitiminde kullanılması sürecinde farklı noktalara odaklandıkları görülmektedir. Bu çalışmada geliştirilmek istenen ölçekle öğretmen adaylarının Web 2.0 araçlarını derslerde kullanımlarına yönelik yetkinlikleri belirlenecektir. Bu açıdan sürecin kapsamlı değerlendirilmesinde geliştirilen bu ölçme aracının alana katkı sunacağı düşünülmektedir.

\section{Yöntem}

$\mathrm{Bu}$ çalışmada öğretmen ve öğretmen adaylarının Web 2.0 araçları kullanım yetkinliği ölçeğine (WAKYÖ) verdikleri cevaplar dikkate alınarak güvenirlik ve geçerlik çalışması 
yapılmaya çalışılmıştır. Ölçeğin geliştirilmesi sürecinde izlenen yol, temel alınan yöntem aşağıda açıklanmıştır.

\section{Çalışma Grubu}

\section{Bu çalışmanın verileri 2019-2020 Eğitim Öğretim Yılı Güz yarı yılında toplanmıştır.}

Bir ölçme aracı geliştirme sürecinde güvenilir ve geçerli sonuçlara ulaşmak açısından kullanılan örneklem büyüklüğü önem taşımaktadır. Çünkü örneklem grubunun yetersiz olması çalışmanın örtük yapısının belirlenmesi sürecindeki açımlayıcı faktör analizi (AFA) ve çalışmanın diğer sonuçlarını olumsuz yönde etkileyebilmektedir. $\mathrm{Bu}$ konuda kullanılabilecek örneklem sayısının 150 (Akt. Tabachnick ve Fidell, 2001) ve 100 ile 200 arası (Kline, 1994) şeklinde olabileceğini belirten araştırmacılar olmakla beraber; sağlıklı bir faktör analizi sürecinde örneklem sayısı olarak 50'inin çok zayıf, 100'ün zayıf, 200'ün orta, 300'ün iyi, 500'ün çok iyi ve 1000 sayısının mükemmel olduğunu belirten çalışmalara da rastlanmaktadır (Comrey ve Lee, 1992). Literatürde temel ölçütün 300 olduğu belirtilmekle beraber, ölçekte yer alan madde sayısının beş veya daha sağlıklı analizler için on katı sayısında bir örneklem grubuna ulaşılması gerektiği aktarılmaktadır (Kass ve Tinsley, 1979). Benzer şekilde Comrey ve Lee (1992) de farklı bir çalışmasında bir ölçme aracı geliştirme sürecinde sağlıklı sonuçlar için örneklem sayısının 300 ile 500 arası olması gerektiğini tavsiye etmektedir. $\mathrm{Bu}$ çalışmanın AFA aşaması için çalışmaya Kilis 7 Aralık Üniversitesi'nde öğrenim gören toplam 409 öğretmen adayı katılmıştır. 409 katılımcının 284'ü kadın, 124'ü ise erkek öğrencilerden oluşmaktadır. AFA'ya ilişkin veriler 2019-2020 eğitim öğretim yılı güz döneminde toplanmıştır. Öğretmen ve öğretmen adaylarına ilişkin sayısal veriler Tablo 2.'de sunulmuştur.

Tablo 2'de görüldüğü gibi katılımcılar farklı branşlardan oluşan öğretmen ve öğretmen adaylarından oluşmaktadır. Öğretmen adaylarının bir kısmını formasyon öğrencileri oluşturmakta olup, katılımcıların bölümlere dağılımı şu şekildedir: sosyal bilgiler (144), coğrafya (73), sınıf (72), Türkçe (46) ve okul öncesi (38) gibi alanlarda öğrenim gören bireylerden oluştuğu görülmektedir. Çalışmanın katılımcıları kolay örnekleme yöntemi ile seçilmiştir. Araştırmacının veri toplama sürecinde sosyal bilgiler öğretmenliği, eğitim fakültesi öğrencileri ve formasyon eğitimi alan öğretmen adaylarına ulaşılmasının daha kolay olması bu grupların örneklem içerisindeki sayılarının fazla olmasında etkili olmuştur. Daha önceden öğretim teknolojileri ve materyal tasarım dersinde Web 2.0 araçlarını kullanan (185) ve kullanmayan (224) tüm öğretmen adaylarına ölçek formu uygulanmıştır. Dolayısıyla rastgele seçilen 185 katılımcı Web 2.0 araçları ile içerik 
hazırlayabilme eğitimi almışken, 224 kişi özel olarak böyle bir eğitim almamıştır. Toplamda 409 katılımcıyla yapılan AFA çalışmalarında katılımcılardan birinin ölçek maddelerinin çoğunu yanıtsız bırakmasından ötürü 1 tane kayıp veri olmuştur. $\mathrm{Bu}$ yüzden AFA çalışmaları 408 katılımcının verileri üzerinden yapılmıştır.

Tablo 2. Çalışma grubu

\begin{tabular}{lcc}
\hline \multicolumn{1}{c}{$\begin{array}{c}\text { Katılımcı öğretmen ve öğretmen } \\
\text { adayları }\end{array}$} & Siklık (f) & Yüzde (\%) \\
\hline Sosyal bilgiler & 144 & 35.2 \\
Coğrafya & 73 & 17.8 \\
Sınıf öğretmenliği & 72 & 17.6 \\
Türkçe öğretmenliği & 46 & 11.2 \\
Okul öncesi öğretmenliği & 38 & 9.3 \\
Felsefe öğretmenliği & 15 & 3.7 \\
Biyoloji öğretmenliği & 7 & 1.7 \\
Türk Dili ve Edebiyatı & 5 & 1.2 \\
öğretmenliği & & \\
Tarih öğretmenliği & 4 & 1.0 \\
Moleküler biyoloji öğretmenliği & 3 & 0.7 \\
Sosyoloji öğretmenliği & 1 & 0.2 \\
Toplam & 408 & 99.8 \\
Kayıp veri & 1 & 0.2 \\
\hline Toplam & 409 & 100 \\
\hline
\end{tabular}

Çalışmanın Doğrulayıcı Faktör Analizi (DFA) aşamasında ise Gaziantep Üniversitesi, Pamukkale Üniversitesi ve Trabzon Üniversite'nde öğrenim gören veya öğrenimini tamamlamış 338 farklı öğretmen adayına ölçeğin AFA süreci sonundaki formu uygulanmıştır. DFA sürecine katılan katılımcıların 92'si erkek, 243'ü kadın ve diğer 3 kişi ise cinsiyetini belirtmeyenlerden oluşmaktadır.

\section{Veri Toplama Aracının Hazırlanması ve Veri Toplama Süreci}

Web 2.0 Araçları Kullanımı Yetkinlik Ölçeği maddeleri oluşturulmadan önce literatür taraması yapılmıştır. Web 2.0 araçlarının eğitim süreçlerinde kullanımına ilişkin makale ve ölçek geliştirme çalışmaları incelenmiştir. Bunun yanı sıra, öğretmen adaylarının Web 2.0 
araçlarıyla hazırladıkları içerikler incelenmiştir. İncelenen içeriklerde yetkin olan öğrencilerin Web 2.0 uygulamasını daha kapsamlı ve etkili nasıl kullandığı gözlemlenmiştir. Örneğin sosyal bilgilerde dijital hikâye hazırlayan bir öğretmen adayının uygulamanın sanal sınıf özelliği ile öğrencilerini sınıfa ekleme, hikayesine; ses, görsel, metin ekleme gibi özellikleri bildiği gözlemlenmiştir. Dolayısıyla taranan literatür (Bişirici, Kul, Aksu, Akaslan ve Çelik, 2017; Kuzu-Demir ve Akbulut, 2017; Tekkurşun, Demir, ve Mutlu Bozkurt, 2019; Çam ve Uysal, 2017; Öztürk ve Horzum, 2011) ve öğretmen adaylarıyla yapılan görüşmelerin incelenmesi sonucu ölçeğin 50 maddelik taslak formu oluşturulmuştur. Hazırlanan form 2 alan uzmanı ve bir Türkçe eğitimi dil uzmanının görüşlerine sunulmuştur. Alınan dönütler neticesinde formda yeni düzenlemeler yapılarak ölçeğin deneme formuna son şekli verilmiştir. Kullanılacak ölçek formu 50 maddeden oluşan Web 2.0 araçları Kullanım Yetkinliğini belirlemek üzere 'Hiçbir Zaman (1), Nadiren (2), Ara Sıra (3), Sıklıkla (4), Her Zaman (5) şeklinde derecelendirilmiş beşli Likert tipinde tasarlanmıştır.

\section{Verilerin Analizi}

Ölçeğin AFA ve güvenirlik analizleri için SPSS programı; faktör yapısının doğrulanması için ise Lisrel 8.72 programı kullanılmıştır. AFA'da ölçme aracında ortaya konmak istenen yapıyı ölçmeyen veya birden fazla boyuta yük veren maddeleri ayrıştırabilme (Worthington ve Whittaker, 2006), ilgili değişkenleri az sayıda, manalı ve bağımsız faktörler haline getirme işlemleri yapılırken (Kalaycı, 2006); DFA'da ise önceden belirlenmiş bir yapının araştırma için toplanan veriler ile ne derece doğrulandığı tespit edilir. Başka bir ifade ile DFA ile hipotezleri test etmek için model ve veri uyumu ile değişkenler arasındaki ilişki incelenir (Kline, 2011; Pohlmann, 2004; Tabachnick ve Fidell, 2007). Bu yüzden DFA sosyal bilimlerde önceden seçilen faktör modelinin veriler ile uyumunu test etmede ve ölçme aracının yapı geçerliğini incelemede güçlü ve tercih edilen bir istatistiki tekniktir (Çokluk, Şekercioğlu \& Büyüköztürk, 2012; Sümer, 2000). Bu çalışmada DFA bağlamında incelenecek olan uyum indeksleri Ki-Kare Uyum İyiliği İndeksi (Chi- Square Goodness of Fit, $\chi 2$ ), Karşılaştırmalı Uyum İndeksi (Comparative Fit Index, CFI), Tucker Levis İndeksiTLI ve Yaklaşık Hataların Ortalama Karekökü (Root Mean Square Error of Approximation, RMSEA) şeklindedir. Güvenirlik çalışması kapsamında uygulanan madde analizi yöntemlerinden madde-toplam korelasyonu, test maddelerinden alınan puanlar ile testin toplam puanı arasındaki ilişkiyi açıklar. Madde-toplam korelasyonunun pozitif ve yüksek olması, maddelerin benzer davranışları örneklediğini gösterir ve testin iç tutarlığının yüksek olduğunu gösterir. Genel olarak madde-toplam korelasyonu .30 ve daha yüksek olan 
maddelerin bireyleri iyi derecede ayırt ettiği, .20-.30 arasında kalan maddelerin zorunlu görülmesi durumunda teste alınabileceği söylenebilir.

Madde analizinde kullanılan diğer bir yöntem alt ve üst çeyrekler t-testidir. Testin toplam puanlarına göre alt-\%27 ve üst-\%27'lik grupların madde ortalama puanları arasındaki farkların ilişkisiz t-testi kullanılarak sınanması sonucunda gruplar arasında anlamlı farklılık çıkması testin iç tutarlığının bir göstergesi olarak değerlendirilir. Her iki analiz maddelerin bireyleri ölçülen davranış bakımından ne derece ayırt ettiğini gösterir. Cronbach Alpha test puanları arasındaki iç tutarlığı incelemek amacıyla kullanılır. Hesaplanan güvenirlik katsayısının .70 ve daha yüksek olması test puanlarının güvenirliği için genel olarak yeterli görülmektedir (Büyüköztürk, 2011).

Ölçek geliştirme sürecinde gerçekleştirilen adımların özeti aşağıda şekil 1.'de sunulmuştur.

\section{A. MADDE HAVUZU OLUȘTURMA}

-Literatür taraması, geliştirilen ölçme araçlarının incelenmesi, Web 2.0 çalışmaları ve öğretmen adayı çalıșmalarının incelenmesi, madde havuzu oluşturma

\section{B. UZMAN GÖRÜȘÜ}

•Uzmanlardan dil, şekil, uygunluk ve anlaşılırlık açısından görüşlerinin alınması

\section{GÜVENIRLIK ÇALIŞMASI}

• Cronbach Alpha İç Tutarlılık Katsayısı, KMO ve Bartlett Testinin yapılması

\section{GEÇERLIK}

-Açımlayıcı faktör analizinin (AFA) yapılması

\section{E. DOĞRULAYICI FAKTÖR ANALIZI (DFA)}

-Uyum indeksleri analizinin yapılması

Şekil 1. WAKYÖ’nün Geliştirilmesi Sürecinde İzlenen Adımlar

\section{Bulgular}

Bu bölümde ölçek geliştirme çalışmasının analiz sonuçlarından elde edilen bulgulara yer verilmiştir.

\section{Geçerliğe İlişkin Bulgular}

$\mathrm{Bu}$ çalışma için toplanan verilerin veri AFA açısından uygun olup olmadığını tespit etmek için Kaiser Meyer Olkin (KMO) örneklem yeterlilik ölçümü ve Bartlett's küresellik testine 
tabi tutulmuştur. KMO katsayısı, veri matrisinin faktör analizi için ugyun olup olmadığ1 hakkında bilgi verir ve .60 'tan yüksek çıkması beklenir. Barlett testi, değişkenler arasında ilişki olup olmadığını kısmi korelasyonlar temelinde inceler. Test sonucunun anlamlı çıkması puanların normalliğinin de bir kanıtı olarak görülebilir (Büyüköztürk, 2011). Elde edilen bulgular aşağıda tablo 3 'te sunulmuştur.

Tablo 3. WAKYÖ'nün KMO ve Bartlett's Küresellik Test Sonuçları

\begin{tabular}{lll}
\hline KMO- Örneklem Yeterlilik Ölçümü & .974 \\
\hline \multirow{2}{*}{ Bartlett's Küresellik Testi } & Yaklaşık Ki-kare & 20718.41 \\
& Serbestlik derecesi & 1225 \\
\hline$* \mathrm{p}<.001$ & Anlamlılık (P) & .000 \\
\hline
\end{tabular}

Tablo 1'de de görüldüğü üzere çalışmanın KMO değeri .97 ve Bartlett Küresellik testi sonucunda anlamlılık değeri ise $\mathrm{p}<.01$ çıkmıştır. Bu sonuç AFA yapmak için örneklemin yeterliği olduğunu göstermektedir.

\section{Açımlayıcı Faktör Analizi (AFA)}

Açımlayıcı faktör analizinden önce veri setinin faktör analizi için uygunluğuna bakılması gerekmektedir. Faktör analizi öncesinde verilerin normal dağılımı için çarpıklık ve basıklık katsayılarından, çoklu bağlantı için maddeler arası korelasyon katsayılarından, doğrusallık kontrolü için korelasyon katsayılarının anlamlılığından yararlanılmıştır. Mükemmel simetrik normal dağılımda, çarpıklık ve basıklık katsayıları sıfıra eşit olmakla birlikte, bir kural olarak çarpıklık ve basıklık için \pm 2 arasındaki değerler normalden önemli bir sapma göstermediği şeklinde yorumlanır (Bachman, 2004). Çarpıklık ve basıklık katsayıları incelendiğinde (Ek-1) her iki katsayının da maddelerin tümü için \pm 2 aralığında olduğu tespit edilmiştir. Bir değişkenin başka bir değişken ile korelasyonu 0,90'dan büyük olması aşırı benzerlik kabul edilmekte ve çoklu bağlantı problemi olarak kabul edilmektedir (Çokluk, Şekercioğlu ve Büyüköztürk, 2012). Ölçekteki maddeler arasındaki korelasyon katsayıları (Ek-2) incelendiğinde en yüksek korelasyon katsayısının .86 olduğu ve çoklu bağlantı sorununun olmadı̆̆ örneklem sayısına göre değişmekte olup pratik çözüm olarak korelasyon katsayısının anlamlılığ1 (p<.05) dikkate alınabilir (Çokluk, Şekercioğlu ve Büyüköztürk, 2012). Maddeler arasındaki korelasyon katsayıları incelendiğinde anlamlı olmayan madde ikilisinin bulunmadığı tespit edilmiştir (Ek-2). Bu çalışmada yapılan Kaiser-Meyer-Oklin'in (KMO) 
ve Barlett Sphericity testleri gerçekleştirilmiş olup, KMO sonucu .97 bulunmuştur. Temelde 0 ile 1 arasında değerler alan KMO'nun değeri 1'e yaklaştıkça örneklemin yeterlilik derecesi yükselir. Bu çalışmada KMO örneklem uygunluk katsayısı .97, Barlett Sphericity testi değeri ise $20718.41(p<.01$, sd $=1225)$ bulunmuştur. Bu sonuca göre, verilerin faktör analizi için mükemmel uygunlukta olduğu söylenebilir. 50 maddeden oluşan ölçek maddeleri döndürme işlemine tabi tutularak faktör yüklerine bakılmış ve ölçeğin temel bileşenlerinin analizi yapılmıştır. Web 2.0 Araçları Kullanım Yetkinliği Ölçeği’nin farklı faktörlere ayrılıp ayrılmadığının tespitinde dik döndürme tekniklerinden "Varimax" kullanılmıştır. Yapılan analiz sonucunda aynı yapıyı ölçmeyen ve faktör yük değerleri istenen yükseklikte olmayan maddeler ölçekten ayıklanır. Büyüköztürk’e (2011) göre bu ayıklama işlemi yapılırken madde faktör yük değerlerinin .45 veya az sayıda madde olan ölçekler için .30 olması, bir maddenin birden fazla faktörde yüksek yük değerleri taşımaması, eğer bir madde iki faktörde birden bulunuyorsa aralarındaki farkın en az .10 değerinde olması, maddelerin ortak faktör varyansının .66'nın üzerinde olması dikkate alınmalıdır. Ortak faktör varyansı her maddenin tüm faktörlerdeki faktör yüklerinin kareleri toplamı ile elde edilmektedir. Maddelerin ortak faktör varyanslarının 1'e yakın ya da 0.66'nın üzerinde olması iyi bir çözüm olmakla birlikte bunu karşılamak genellikle zordur. Ortak faktör varyansının yüksek olmasının, modele ilişkin açıklanan toplam varyansı artıracağı dikkate alınmalıdır (Çokluk, Şekercioğlu, Büyüköztürk, 2012). Faktör sayısını belirlemek için özdeğerler, yamaç birikinti grafiği ve faktörlerin açıkladıkları varyanslar arasındaki fark incelenmiştir. Yamaç birikinti grafiği incelendiğinde 2. faktörden itibaren eğimin yataya döndüğü görülmektedir. Özdeğerler incelendiğinde ise birinci faktörün özdeğerinin 27.54, ikinci faktörün 3.02 olduğu ve birinci özdeğerin ikinci özdeğere oranının 8 kat daha yüksek olduğu tespit edilmiştir. Tek faktör kuralı uygulanarak gerçekleştirilen faktör analizinde açıklanan varyans \%55.07 ve iki faktör kuralı uygulanarak gerçekleştirilen faktör analizinde açıklanan varyans \%61.10 olarak tespit edilmiştir.

Tek faktörlü yapı incelendiğinde (Tablo 4) en düşük faktör yükünün .46 olduğu, diğer bir ifadeyle faktör yükü .40'tan düşük madde bulunmadığı, maddelerin ortak faktör varyansları incelendiğinde 11 maddenin $(\mathrm{m} 1, \mathrm{~m} 2, \mathrm{~m} 3, \mathrm{~m} 4, \mathrm{~m} 9, \mathrm{~m} 16, \mathrm{~m} 29, \mathrm{~m} 36, \mathrm{~m} 37, \mathrm{~m} 38$, m46) ortak faktör varyansının <.50 olduğu ve açıklanan toplam varyansın \%55.07 düzeyinde olduğu tespit edilmiştir. En düşük ortak faktör varyansına sahip olan maddeden başlamak üzere söz konusu maddeler aşamalı olarak çıkarıldığında sorunlu maddelerin ortak varyansının değişmediği ve sorunlu tüm maddelerin çıkarılması gerektiği anlaşılmıştır. 


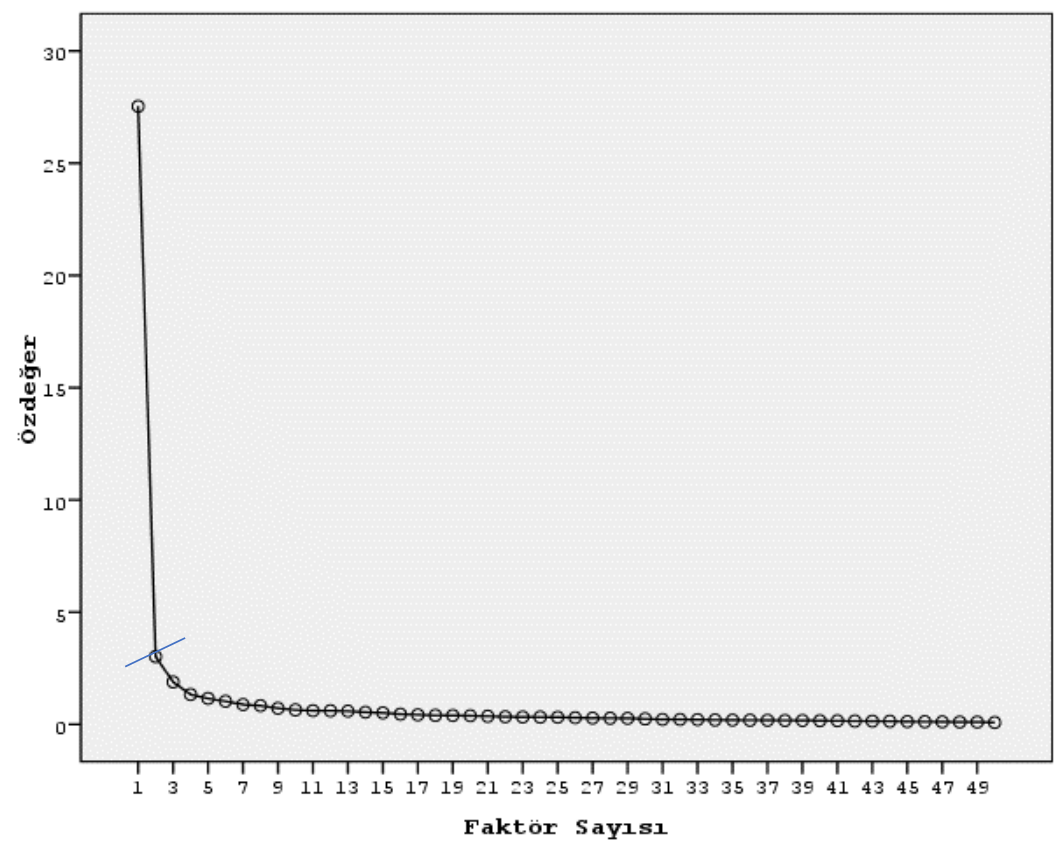

\section{Şekil 2. Faktör Özdeğerlerine İlişkin Yamaç Eğim Grafiği}

Ölçekten 11 maddenin çıkarılması ile açıklanan varyansın \%60.44 düzeyine ulaştığı ve 11 maddenin çıkarılması ile kalan 39 maddenin açıkladığı toplam varyansın, 50 maddeden oluşan yapıya göre daha yüksek bir varyans açıklama gücüne sahip olduğu tespit edilmiştir. AFA ile elde edilen sonuçlar yamaç birikinti grafiği ve özdeğer farkına paralel bir şekilde ölçeğin tek faktörlü yapısını desteklemektedir.

Kontrol amaçlı olarak ölçeğin iki faktörlü yapısı incelenmiştir (Tablo 5). Madde eksiltmeden gerçekleştirilen AFA sonucunda ölçekteki maddelerin ait oldukları faktörlerdeki en düşük faktör yükünün .46 olduğu, diğer bir ifadeyle faktör yükü .40'tan düşük madde bulunmadığı, buna karşın iki faktördeki faktör yükleri arasındaki fark .10'dan düşük olan 5 madde (m4, m29, m33, m47, m50) bulunduğu, Maddelerin ortak faktör varyansları incelendiğinde 5 maddenin $(\mathrm{m} 1, \mathrm{~m} 2, \mathrm{~m} 9, \mathrm{~m} 16, \mathrm{~m} 29)$ ortak faktör varyansının .50 ve altında olduğu ve açıklanan toplam varyansın \%61.10 düzeyinde olduğu tespit edilmiştir. En düşük ortak faktör varyansına sahip olan maddeden başlamak üzere binişik ve ortak faktör varyansı düşük maddeler aşamalı olarak çıkarıldığında sorunlu maddelerin değişmediği ve sorunlu tüm maddelerin çıkarılması gerektiği anlaşılmıştır. 
Tablo 4. Web 2. 0 araçları kullanımı yetkinliği ölçeği tek boyutlu AFA sonuçları

\section{Ortak}

MaddeFaktör Faktör Faktör

Faktör Ortak Faktör

No Yükü Varyansı yükü ${ }^{1}$ Madde No Yükü Varyansı Faktör yükü

\begin{tabular}{|c|c|c|c|c|c|c|c|}
\hline$\overline{\mathrm{m} 1}$ & 0.46 & 0.21 & & $\mathrm{~m} 26$ & 0.80 & 0.63 & 0.81 \\
\hline $\mathrm{m} 2$ & 0.61 & 0.37 & & $\mathrm{~m} 27$ & 0.72 & 0.52 & 0.74 \\
\hline$\overline{\mathrm{m} 3}$ & 0.68 & 0.46 & & $\mathrm{~m} 28$ & 0.72 & 0.52 & 0.75 \\
\hline $\mathrm{m} 4$ & 0.71 & 0.50 & & $\mathrm{~m} 29$ & 0.69 & 0.48 & \\
\hline$\overline{\mathrm{m} 5}$ & 0.78 & 0.61 & 0.78 & $\mathrm{~m} 30$ & 0.74 & 0.55 & 0.75 \\
\hline $\mathrm{m} 6$ & 0.78 & 0.61 & 0.78 & m31 & 0.72 & 0.52 & 0.71 \\
\hline $\mathrm{m} 7$ & 0.81 & 0.65 & 0.82 & $\mathrm{~m} 32$ & 0.72 & 0.52 & 0.72 \\
\hline$\overline{\mathrm{m} 8}$ & 0.79 & 0.63 & 0.80 & m33 & 0.74 & 0.55 & 0.74 \\
\hline$\overline{\mathrm{m} 9}$ & 0.70 & 0.50 & & m34 & 0.76 & 0.58 & 0.76 \\
\hline $\mathrm{m} 10$ & 0.82 & 0.68 & 0.83 & m35 & 0.71 & 0.51 & 0.70 \\
\hline$\overline{\mathrm{m} 11}$ & 0.77 & 0.60 & 0.78 & m36 & 0.51 & 0.26 & \\
\hline $\mathrm{m} 12$ & 0.80 & 0.64 & 0.82 & m37 & 0.49 & 0.24 & \\
\hline $\mathrm{m} 13$ & 0.78 & 0.61 & 0.80 & m38 & 0.57 & 0.32 & \\
\hline$\overline{\mathrm{m} 14}$ & 0.72 & 0.51 & 0.72 & m39 & 0.79 & 0.62 & 0.80 \\
\hline $\mathrm{m} 15$ & 0.77 & 0.59 & 0.77 & $\mathrm{~m} 40$ & 0.80 & 0.64 & 0.81 \\
\hline$\overline{\mathrm{m} 16}$ & 0.62 & 0.38 & & $\mathrm{~m} 41$ & 0.80 & 0.65 & 0.82 \\
\hline $\mathrm{m} 17$ & 0.71 & 0.51 & 0.71 & $\mathrm{~m} 42$ & 0.83 & 0.68 & 0.84 \\
\hline $\mathrm{m} 18$ & 0.81 & 0.66 & 0.82 & $\mathrm{~m} 43$ & 0.77 & 0.60 & 0.76 \\
\hline m19 & 0.82 & 0.67 & 0.83 & $\mathrm{~m} 44$ & 0.75 & 0.56 & 0.73 \\
\hline $\mathrm{m} 20$ & 0.80 & 0.64 & 0.83 & $\mathrm{~m} 45$ & 0.72 & 0.52 & 0.71 \\
\hline $\mathrm{m} 21$ & 0.82 & 0.68 & 0.84 & $\mathrm{~m} 46$ & 0.70 & 0.49 & \\
\hline $\mathrm{m} 22$ & 0.79 & 0.62 & 0.79 & $\mathrm{~m} 47$ & 0.77 & 0.59 & 0.76 \\
\hline$\overline{\mathrm{m} 23}$ & 0.80 & 0.64 & 0.80 & $\mathrm{~m} 48$ & 0.80 & 0.64 & 0.82 \\
\hline $\mathrm{m} 24$ & 0.83 & 0.69 & 0.83 & $\mathrm{~m} 49$ & 0.77 & 0.60 & 0.77 \\
\hline$\overline{\mathrm{m} 25}$ & 0.76 & 0.58 & 0.74 & $\mathrm{~m} 50$ & 0.72 & 0.52 & 0.71 \\
\hline
\end{tabular}

Açıklanan Toplam Varyans (\%) (50 madde ile): 55.07

Açıklanan Toplam Varyans (\%) (39 madde ile): 60.44

111 madde çıkarıldıktan sonra 
Ölçekten 9 maddenin çıkarılması ile açıklanan varyansın \%64.11 düzeyine ulaştığı ve 9 maddenin çıkarılması ile kalan 41 maddenin açıkladığı toplam varyansın, 50 maddeden oluşan yapıya göre daha yüksek bir varyans açıklama gücüne sahip olduğu tespit edilmiştir.

Tablo 5. Web 2. 0 araçları kullanımı yetkinliği ölçeği iki boyutlu AFA sonuçları

\begin{tabular}{|c|c|c|c|c|c|c|c|}
\hline \multirow{2}{*}{$\begin{array}{l}\text { Madde } \\
\text { No }\end{array}$} & \multicolumn{2}{|c|}{ Faktör Yükü } & \multirow{2}{*}{$\begin{array}{c}\text { Ortak Faktör } \\
\text { Varyansı }\end{array}$} & \multirow[b]{2}{*}{ Madde No } & \multicolumn{2}{|c|}{ Faktör Yükü } & \multirow[b]{2}{*}{ Ortak Faktör Varyansı } \\
\hline & F1 & F2 & & & F1 & $\mathbf{F 2}$ & \\
\hline$\overline{\mathrm{m} 1}$ & 0.18 & $\mathbf{0 . 5 3}$ & 0.32 & $\mathrm{~m} 26$ & 0.72 & 0.36 & 0.65 \\
\hline$\overline{\mathrm{m} 2}$ & 0.33 & 0.59 & 0.45 & $\mathrm{~m} 27$ & 0.76 & 0.18 & 0.61 \\
\hline $\mathrm{m} 3$ & 0.42 & 0.58 & 0.51 & $\mathrm{~m} 28$ & 0.76 & 0.17 & 0.61 \\
\hline$\overline{\mathrm{m} 4}$ & 0.51 & 0.51 & 0.52 & $\mathrm{~m} 29$ & 0.53 & 0.45 & 0.48 \\
\hline $\mathrm{m} 5$ & 0.69 & 0.37 & 0.62 & $\mathrm{~m} 30$ & 0.68 & 0.33 & 0.57 \\
\hline $\mathrm{m} 6$ & 0.69 & 0.39 & 0.62 & $\mathrm{~m} 31$ & 0.47 & 0.59 & 0.57 \\
\hline$\overline{\mathrm{m} 7}$ & 0.77 & 0.30 & 0.69 & $\mathrm{~m} 32$ & 0.63 & 0.36 & 0.52 \\
\hline$\overline{\mathrm{m} 8}$ & 0.79 & 0.26 & 0.69 & m33 & 0.54 & 0.52 & 0.57 \\
\hline $\mathrm{m} 9$ & 0.57 & 0.42 & 0.50 & $\mathrm{~m} 34$ & 0.61 & 0.46 & 0.58 \\
\hline$\overline{\mathrm{m} 10}$ & 0.79 & 0.31 & 0.72 & $\mathrm{~m} 35$ & 0.45 & 0.59 & 0.55 \\
\hline $\mathrm{m} 11$ & 0.72 & 0.32 & 0.62 & m36 & 0.06 & 0.80 & 0.64 \\
\hline $\mathrm{m} 12$ & 0.83 & 0.21 & 0.74 & m37 & 0.06 & 0.76 & 0.58 \\
\hline $\mathrm{m} 13$ & 0.82 & 0.20 & 0.70 & m38 & 0.16 & 0.75 & 0.59 \\
\hline $\mathrm{m} 14$ & 0.64 & 0.33 & 0.53 & m39 & 0.71 & 0.36 & 0.63 \\
\hline $\mathrm{m} 15$ & 0.74 & 0.28 & 0.63 & $\mathrm{~m} 40$ & 0.73 & 0.35 & 0.66 \\
\hline $\mathrm{m} 16$ & 0.34 & 0.59 & 0.46 & $\mathrm{~m} 41$ & 0.74 & 0.35 & 0.67 \\
\hline $\mathrm{m} 17$ & 0.62 & 0.36 & 0.51 & $\mathrm{~m} 42$ & 0.75 & 0.37 & 0.70 \\
\hline $\mathrm{m} 18$ & 0.73 & 0.37 & 0.67 & $\mathrm{~m} 43$ & 0.46 & 0.68 & 0.67 \\
\hline$\overline{\mathrm{m} 19}$ & $\mathbf{0 . 8 0}$ & 0.29 & 0.72 & $\mathrm{~m} 44$ & 0.39 & 0.74 & 0.70 \\
\hline $\mathrm{m} 20$ & 0.84 & 0.21 & 0.74 & $\mathrm{~m} 45$ & 0.39 & 0.70 & 0.64 \\
\hline$\overline{\mathrm{m} 21}$ & 0.78 & 0.33 & 0.71 & $\mathrm{~m} 46$ & 0.33 & 0.75 & 0.66 \\
\hline $\mathrm{m} 22$ & 0.65 & 0.45 & 0.62 & $\mathrm{~m} 47$ & 0.54 & 0.56 & 0.61 \\
\hline $\mathrm{m} 23$ & 0.66 & 0.45 & 0.64 & $\mathrm{~m} 48$ & 0.73 & 0.35 & 0.66 \\
\hline $\mathrm{m} 24$ & 0.72 & 0.42 & 0.69 & $\mathrm{~m} 49$ & 0.61 & 0.48 & 0.60 \\
\hline $\mathrm{m} 25$ & 0.47 & 0.66 & 0.65 & m50 & 0.48 & 0.58 & 0.55 \\
\hline \multicolumn{5}{|c|}{ Açıklanan Varyans (\%) (50 madde ile) (\%61.10) } & 38.48 & 22.62 & \\
\hline \multicolumn{8}{|c|}{ Açıklanan Toplam Varyans (\%) (39 madde ile) } \\
\hline \multicolumn{5}{|c|}{$(\% 64.11)$} & 43.29 & 20.82 & \\
\hline
\end{tabular}


Ölçeğin tek ve iki faktörlü yapılarından elde edilen toplam varyans oranları (\%60.11 ve \%64.11) farkının \%4 düzeyinde olduğu görülmektedir. En uygun faktör yapısının belirlenmesinde yamaç birikinti grafiği ve özdeğerin yanı sıra farklı kaynaklarda (Seçer, 2015: 85) faktör sayısının belirlenmesinde her bir faktörün toplam varyansın \%5'ini açıklaması yeterli görülmüştür. Tek faktörlü yapıda elde edilen varyans oranı ile farkın \%5'ten düşük (64.10-60.44=3.67) olduğu ve yamaç birikinti grafiği ile birlikte dikkate alındığında tek faktörlü yapının daha uygun olduğu kabul edilmiştir. AFA sonuçlarının doğrulanması için Doğrulayıcı Faktör Analizi (DFA) sonuçlarının da incelenmesi gerekmektedir.

\section{Doğrulayıcı Faktör Analizi (DFA)}

Doğrulayıcı faktör analizi (DFA) gizil değişkenler ile ilgili kuramların test edilmesine dayanan ve ileri düzey araştırmalarda kullanımı tercih edilen oldukça gelişmiş bir tekniktir (Tabachnick ve Fidell, 2001). Doğrulayıcı faktör analiziyle daha önceden doğrulanmış bir modelin doğrulanıp doğrulanmadığının test edilmesi amaçlanır. Bu yöntemle elde edilen faktör yapılarının geçerliği test edilmiş olur. $\mathrm{Bu}$ yönüyle DFA açımlayıcı faktör analizi sonucu elde edilen faktör yapılarının test edilip doğrulanmasını sağlamış olur (Özdamar, 2016). DFA sonucu WAKYÖ maddelerinin standardize edilmiş değerleri aşağıda şekil 3'te sunulmuştur.

Şekil 3. DFA Sonucunda WAKYÖ Maddelerinin Standardize Edilmiş Değerleri.

Bu çalışmanın AFA sonuçlarının DFA'ya uygunluğu; Ortalama Hataların Karekökü (Root Mean Square Error of Approximation; RMSEA) ve Karşılaştırmalı Uygunluk İndeksi (Comparative Fit Index; CFI) ölçütleri ile test edilmiştir. Analiz sonuçlarının değerlendirilmesinde; Normlaştırılmış Ki-Kare $(\chi 2 / s d)$, Yaklaşık Hataların Ortalama Karekökü (RMSEA); Karşılaştırmalı Uyum Endeksi (CFI); göstergeleri kullanılmıştır. (Tabachnick ve Fidell, 2001; Sümer, 2000; Brown, 2006; Jöreskog ve Sörbom, 1993; Raykov ve Marcoulides, 2008; Schumacker ve Lomax, 1996; Kelloway, 1989; Hu ve Bentler, 1999; Kline, 2005; Thompson,2004; Akt. Çokluk, Şekercioğlu, Büyüköztürk, 2012). 


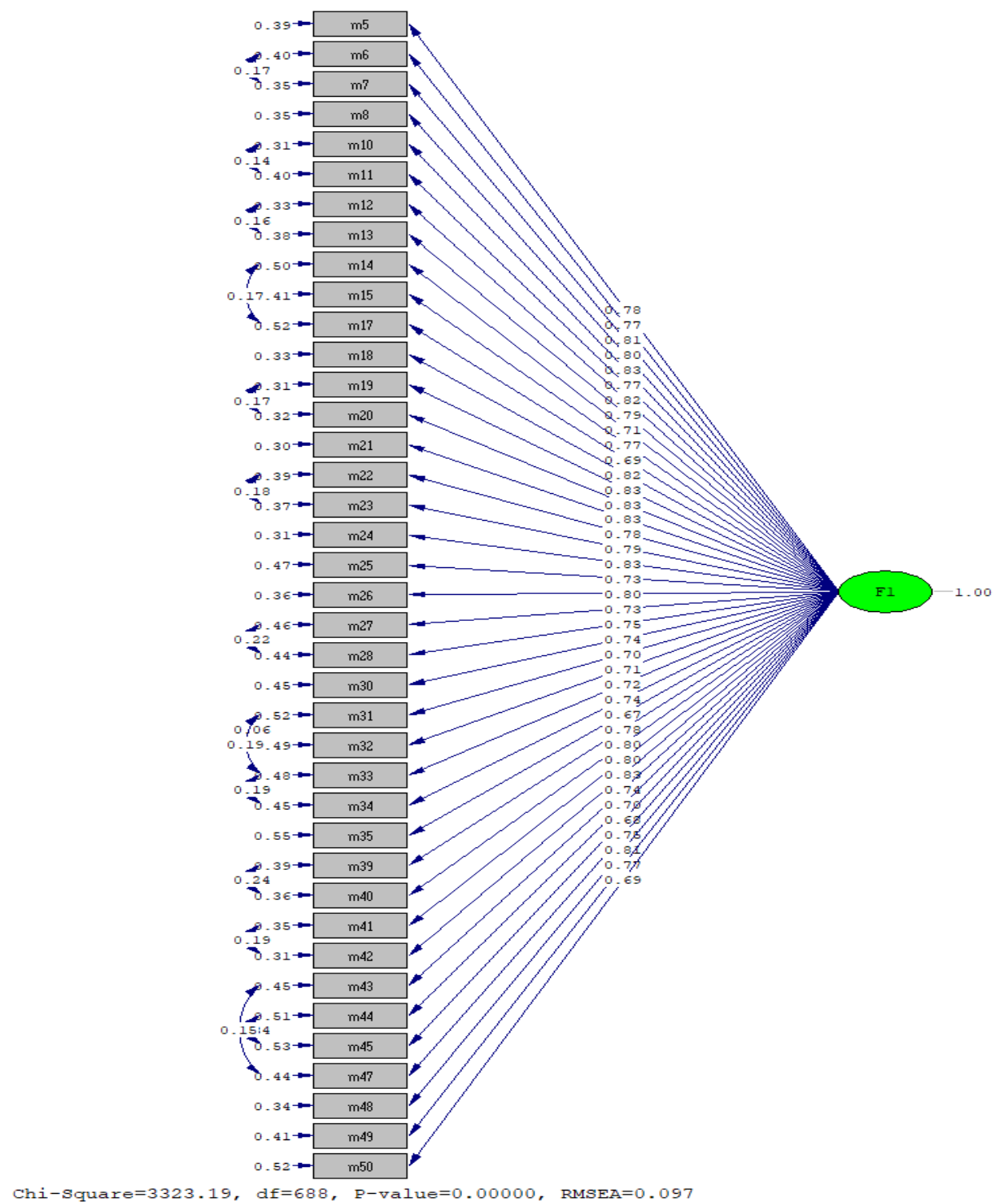

$\mathrm{Bu}$ çalışmaya ait DFA değerleri ve ölçüt alınan kesme noktaları aşağıda Tablo 6'da sunulmuştur

Tablo 6. Doğrulayıcı Faktör Analizi Sonuçları ve Kesme Noktaları

\section{WAKYÖ İçin Uyum değerleri}

\begin{tabular}{lccc}
\hline $\begin{array}{l}\text { Model uyum } \\
\text { indeksi }\end{array}$ & $\begin{array}{c}\text { Kabul için } \\
\text { kesme noktasi }\end{array}$ & $\begin{array}{c}\text { Modifikasyon } \\
\text { öncesi }\end{array}$ & Modifikasyon sonrasi \\
\hline$\chi 2 /$ df & $2 \leq \chi 2 / \mathrm{df} \leq 5$ & 8.27 & 4.83 \\
CFI & $>0.90$ & .97 & .98 \\
REMSEA & $\leq 0.10$ & .134 & .097 \\
TLI & $>0.90$ & .97 & .98 \\
\hline
\end{tabular}


Tablo 6'daki doğrulayıcı faktör analizi sonuçlarına göre; WAKYÖ’nün uyum indeksi değerleri modifikasyon öncesi sırasıyla; $\chi 2$ /df: 8.27; RMSEA: 0.134, CFI=.97 ve TLI .97 ve modifikasyon sonras1 $\chi 2$ df: 4.83; RMSEA: 0.097, CFI=.98 ve TLI .98 olarak bulunmuştur. Modifikasyonlar sonrası elde edilen sonuçların kabul edilebilir aralık değerleri arasında olduğu görülmektedir. $\mathrm{Bu}$ çalışmada geliştirilen ölçek araştırmacı tarafından hazırlanmış olup yapılan modifikasyonlar maddelerin taşıdıkları anlamlar üzerinden "kabul edilebilir mantıksal mantığa dayandırılarak" (Çokluk, Şekercioğlu ve Büyüköztürk, 2012) gerçekleştirilmiştir (Tablo 7).

Tablo 7. Kovaryans bağlantısı kurulan madde çiftleri ve mantıksal dayanak

\begin{tabular}{|c|c|c|c|}
\hline Madde & & Madde & Mantıksal dayanak \\
\hline $\begin{array}{l}\text { 6. Web } 2.0 \text { araçları ile etkili } \\
\text { sunumlar hazırlayabilirim. } \\
\text { (Prezi, Powtoon, Buncee, } \\
\text { Emaze... gibi) }\end{array}$ & $\leftrightarrow$ & $\begin{array}{l}\text { 7. Web } 2.0 \text { araçları ile bir } \\
\text { konudaki bilgi ve kavramları } \\
\text { zihin haritası şeklinde } \\
\text { sunabilirim. (Wisemapping, } \\
\text { Pooplet, } \\
\text { SpiderScribe,Gocongr...gibi) }\end{array}$ & $\begin{array}{l}\text { Görsel sunum } \\
\text { yapabilme becerisi }\end{array}$ \\
\hline $\begin{array}{l}\text { 10. Web } 2.0 \text { araçları ile dijital } \\
\text { panolar hazırlayabilirim. (Padlet, } \\
\text { Bendspace, Lino ti...gibi) }\end{array}$ & $\leftrightarrow$ & $\begin{array}{l}\text { 11. Web } 2.0 \text { araçları ile } \\
\text { poster hazırlayabilirim. } \\
\text { (Word art, Sketch toy...gibi) }\end{array}$ & $\begin{array}{l}\text { Pano ve poster } \\
\text { benzer beceriler } \\
\text { gerektirmektedir. }\end{array}$ \\
\hline $\begin{array}{l}\text { 12. Web } 2.0 \text { araçları ile } \\
\text { karikatür hazırlayabilirim. (Make } \\
\text { Beliefs Comix, Toondoo...gibi) }\end{array}$ & $\leftrightarrow$ & $\begin{array}{l}\text { 13. Web } 2.0 \text { araçları ile } \\
\text { dijital hikâye oluşturabilirim. } \\
\text { (Storyjumper, Storybird, } \\
\text { Pixton...gibi) }\end{array}$ & $\begin{array}{l}\text { Karikatürler de } \\
\text { hikâye } \\
\text { anlatmaktadır }\end{array}$ \\
\hline $\begin{array}{l}\text { 14. Web } 2.0 \text { araçları ile sanal } \\
\text { yazarlık yapabilirim. (Wattpad, } \\
\text { Blogger...gibi) }\end{array}$ & $\leftrightarrow$ & $\begin{array}{l}\text { 17. Web } 2.0 \text { araçları ile blog } \\
\text { oluşturabilirim. (Blogger, } \\
\text { Tumblr... gibi) }\end{array}$ & $\begin{array}{l}\text { Blog } \\
\text { oluşturabilmek için } \\
\text { yazarlık becerisi } \\
\text { gereklidir. }\end{array}$ \\
\hline $\begin{array}{l}\text { 19. Web } 2.0 \text { araçları ile bulmaca } \\
\text { oluşturabilirim. (Mentimeter, } \\
\text { Flipquiz... gibi) }\end{array}$ & $\leftrightarrow$ & $\begin{array}{l}\text { 20. Web } 2.0 \text { araçları ile } \\
\text { yapboz oluşturabilirim. } \\
\text { (Puzzlemaker, } \\
\text { LearningApss...gibi) }\end{array}$ & $\begin{array}{l}\text { Bu bütünlüğü } \\
\text { oluşturma işlemi } \\
\text { zihinsel beceri } \\
\text { gerektiren bir } \\
\text { durumdur. }\end{array}$ \\
\hline
\end{tabular}

22. Web 2. 0 araçları ile açık $\leftrightarrow$ 23. Web 2. 0 araçları ile kısa Her iki maddede 


\begin{tabular}{|c|c|c|c|}
\hline $\begin{array}{l}\text { uçlu sınavlar hazırlayabilirim. } \\
\text { (Kahoot, Socrative, Mentimeter, } \\
\text { Quizziz... gibi) }\end{array}$ & & $\begin{array}{l}\text { cevapli sınavlar } \\
\text { hazırlayabilirim. (Kahoot, } \\
\text { Socrative, Mentimeter, } \\
\text { Quizziz... gibi) }\end{array}$ & $\begin{array}{l}\text { sinav hazırlama } \\
\text { becerisi yer } \\
\text { almaktadır }\end{array}$ \\
\hline $\begin{array}{l}\text { 27. Web } 2.0 \text { araçları ile } \\
\text { infografik hazırlayabilirim. } \\
\text { (Pictochart, Venngage... gibi) }\end{array}$ & $\leftrightarrow$ & $\begin{array}{l}\text { 28. Web } 2.0 \text { araçları ile } \\
\text { artırılmış gerçeklik } \\
\text { etkinlikleri tasarlayabilirim. } \\
\text { (Quiver, Morfo, Urasma... } \\
\text { gibi) }\end{array}$ & $\begin{array}{l}\text { İnfografikler } \\
\text { artırılmış gerçeklik } \\
\text { etkinlikleridir }\end{array}$ \\
\hline $\begin{array}{l}\text { 31. Web } 2.0 \text { araçları ile } \\
\text { fotoğraflarımı düzenleyebilirim. } \\
\text { (Gimps, Photostory, OpenShot... } \\
\text { gibi) }\end{array}$ & $\leftrightarrow$ & $\begin{array}{l}\text { 32. Web } 2.0 \text { araçları ile } \\
\text { filmler oluşturabilirim. } \\
\text { (Mowimaker, Photostory... } \\
\text { gibi) }\end{array}$ & $\begin{array}{l}\text { Film ve fotoğraf } \\
\text { oluşturma ve } \\
\text { düzenleme görsel } \\
\text { düzenleme becerisi } \\
\text { gerektirmektedir }\end{array}$ \\
\hline $\begin{array}{l}\text { 31. Web } 2.0 \text { araçları ile } \\
\text { fotoğraflarımı düzenleyebilirim. } \\
\text { (Gimps, Photostory, OpenShot... } \\
\text { gibi) }\end{array}$ & $\leftrightarrow$ & $\begin{array}{l}\text { 33. Web } 2.0 \text { araçları ile } \\
\text { videolarımı düzenleyebilirim. } \\
\text { (Mowimaker, Photostory, } \\
\text { Safeshare, Filmora... gibi) }\end{array}$ & $\begin{array}{l}\text { Görsel düzenleme } \\
\text { yapabilme becerisi }\end{array}$ \\
\hline $\begin{array}{l}\text { 33. Web } 2.0 \text { araçları ile } \\
\text { videolarımı düzenleyebilirim. } \\
\text { (Mowimaker, Photostory, } \\
\text { Safeshare, Filmora... gibi) }\end{array}$ & & $\begin{array}{l}\text { 34. Web } 2.0 \text { araçları ile } \\
\text { videolarımı istenmeyen } \\
\text { eklentilerden arındırabilirim. } \\
\text { (Safeshare... gibi) }\end{array}$ & $\begin{array}{l}\text { Videoları } \\
\text { istenmeyen } \\
\text { eklentilerden } \\
\text { arındırma video } \\
\text { düzenleme } \\
\text { becerisidir }\end{array}$ \\
\hline $\begin{array}{l}\text { 39. Web } 2.0 \text { araçları ile } \\
\text { oluşturduğum zihin haritalarına } \\
\text { video ekleyebilirim. } \\
\text { (Wisemapping, Poplet... gibi) }\end{array}$ & & $\begin{array}{l}\text { 40. Web } 2.0 \text { araçları ile } \\
\text { oluşturduğum zihin } \\
\text { haritalarına ses ekleyebilirim. } \\
\text { (Wisemapping, Poplet gibi) }\end{array}$ & $\begin{array}{l}\text { Her iki durumda da } \\
\text { zihin haritasına } \\
\text { medya } \\
\text { eklenmektedir. }\end{array}$ \\
\hline $\begin{array}{l}\text { 41. Web } 2.0 \text { araçları ile } \\
\text { oluşturduğum zihin haritalarına } \\
\text { resim ekleyebilirim. } \\
\text { (Wisemapping, Poplet...gibi) }\end{array}$ & $\leftrightarrow$ & $\begin{array}{l}\text { 42. Web } 2.0 \text { araçları ile } \\
\text { oluşturduğum zihin } \\
\text { haritalarına metin } \\
\text { ekleyebilirim. (Wisemapping, } \\
\text { Poplet...gibi) }\end{array}$ & $\begin{array}{l}\text { Zihin haritalarına } \\
\text { eklenti yapabilme } \\
\text { becerisi }\end{array}$ \\
\hline
\end{tabular}


45. Web 2. 0 araçları ile

44. Web 2. 0 araçları ile derslere öğrenci katılımını sağlayabilirim. oluşturduğum uygulamalar sayesinde dersi eğlenceli hale getirebilirim.

43. Web 2. 0 araçları ile oluşturduğum uygulamaları derste kullanabilirim.
Derslerin eğlenceli hale getirilmesi öğrenci katılımını sağlamaktadır

Her iki seçenekte de ders için uygulama geliştirme

Modifikasyon öncesi DFA sonuçlarına göre faktör yüklerinin .50'nin üzerinde olduğu, $X^{2} /$ df ve RMSEA uyum indeksinin kabul edilebilir düzeyde olmadığı (>.10) tespit edilmiştir. İstatistiksel olarak önerilen modifikasyonlara uygun olarak 14 madde çifti arasinda (m6-m7, m10-m11, m12-m13, m14-m17, m19-m20, m22-m23, m27-m28, m31m32, m31-m33, m33-m34, m39-m40, m41-m42, m43-m47, m44-m45) gerçekleştirilen kovaryans bağlantıları sonrası diğer uyum indeksleri gibi RMSEA indeksinin de kabul edilebilir seviyelere $(<.10)$ ulaştı̆gı tespit edilmiştir. Geçerlik analizi sonuçlarına göre ölçeğin 39 madde ve tek faktörlü yapısı ile geçerli bir ölçek olduğu tespit edilmiştir.

\section{Madde Analizi ve Güvenirliğe İlişkin Bulgular}

Bir ölçeğin geçerlik çalışmaları sonrasında güvenirlik analizlerinin yapılması gerekmektedir. Bir testten alınan sonuçların kararlılık göstermesi ve farklı zamanlardaki uygulamalarda belirgin bir değişim göstermemesi olan güvenirlik, testin hatalardan arınık olmasıyla da yakından ilişkilidir (Seçer, 2015). Tablo 8'de madde analizi ve güvenirlik bulgularına yer verilmiştir.

Tablo 8'deki güvenirlik analizi sonuçları incelendiğinde ölçeğin Cronbach Alpha katsayısı 98 düzeyinde oldukça yüksek bulunmuştur. Ölçekteki tüm maddeler için maddetoplam korelasyonlarının .30'dan yüksek (.69 ile .83 aralığında) olduğu, ölçekten herhangi bir maddenin çıkarılması durumunda Cronbach Alpha katsayısının değişmediği, tüm maddelerin alt ve üst $\% 27^{\prime}$ lik grupların $(\mathrm{n} 1=\mathrm{n} 2=110)$ madde puan ortalamalarının karşılaştırılmasına ait $\mathrm{t}$ değerlerinin .01 düzeyinde anlamlı olduğu görülmektedir. $\mathrm{Bu}$ sonuçlar, ölçekte yer alan maddelerin geçerliklerinin yüksek olduğu, ölçmek istenen davranış bakımından örneklemi ayırt ettikleri ve ölçeklerde yer alan maddelerin ölçek içinde aynı davranışı ölçmeye yönelik maddeler olduklarını göstermektedir. 
Tablo 8. Web 2. 0 araçları kullanımı yetkinliği ölçeği madde analizi ve güvenirliği

\begin{tabular}{|c|c|c|c|c|c|c|c|c|c|c|}
\hline Mad & & & & $\mathbf{t}$ & & & & & & $\mathbf{t}$ \\
\hline No & $\overline{\mathbf{x}} \quad \mathrm{SS}$ & $\mathbf{r}$ & $\alpha^{1}$ & $(\mathbf{n} 1=\mathbf{n} 2=110)$ & ) Madde No & $\overline{\mathrm{x}}$ & SS & $\mathbf{r}$ & $\alpha^{1}$ & $(\mathrm{n} 1=\mathrm{n} 2=110)$ \\
\hline 5 & 2.921 .41 & 0.77 & 0.98 & $-26.13 * *$ & $\mathrm{~m} 27$ & 2.39 & 1.36 & 0.73 & 0.98 & $-21.85 * *$ \\
\hline 6 & 3.111 .43 & 0.76 & 0.98 & $-24.34 * *$ & $\mathrm{~m} 28$ & 2.52 & 1.41 & 0.73 & 0.98 & $-22.70 * *$ \\
\hline n7 & 2.891 .47 & 0.80 & 0.98 & $-31.44 * *$ & $\mathrm{~m} 30$ & 2.61 & 1.37 & 0.74 & 0.98 & $-20.80 * *$ \\
\hline $\mathrm{n} 8$ & 2.751 .47 & 0.79 & 0.98 & $-29.53 * *$ & m31 & 3.28 & 1.41 & 0.69 & 0.98 & -18.82 \\
\hline 110 & 2.721 .47 & 0.82 & 0.98 & $-33.12 * *$ & $\mathrm{~m} 32$ & 2.68 & 1.44 & 0.71 & 0.98 & $-20.17 * *$ \\
\hline n11 & 2.841 .44 & 0.76 & 0.98 & $-28.40 * *$ & m33 & 3.04 & 1.47 & 0.73 & 0.98 & $-21.81^{*}$ \\
\hline 112 & 2.611 .48 & 0.81 & 0.98 & $-32.04 * *$ & m34 & 2.92 & 1.51 & 0.75 & 0.98 & $-24.01 * *$ \\
\hline 13 & 2.601 .50 & 0.78 & 0.98 & $-29.62 * *$ & $\mathrm{~m} 35$ & 3.26 & 1.50 & 0.69 & 0.98 & -19 . \\
\hline 114 & 2.711 .44 & 0.70 & 0.98 & $-21.49 * *$ & m39 & 2.86 & 1.49 & 0.78 & 0.98 & -27. \\
\hline 115 & 2.801 .49 & 0.76 & 0.98 & $-26.97 * *$ & $\mathrm{~m} 40$ & 2.76 & 1.48 & 0.80 & 0.98 & $-28.04 *$ \\
\hline 117 & 2.631 .38 & 0.70 & 0.98 & $-21.67 * *$ & $\mathrm{~m} 41$ & 2.85 & 1.50 & 0.81 & 0.98 & $-31.39 * *$ \\
\hline$n 18$ & 2.891 .60 & 0.80 & 0.98 & $-37.88 * *$ & $\mathrm{~m} 42$ & 2.93 & 1.53 & 0.83 & 0.98 & $-31.43 * *$ \\
\hline n19 & 2.741 .56 & 0.82 & 0.98 & $-36.81 * *$ & $\mathrm{~m} 43$ & 3.50 & 1.42 & 0.74 & 0.98 & $-21.74 * *$ \\
\hline $\mathrm{n} 20$ & 2.651 .58 & 0.81 & 0.98 & $-42.54 * *$ & $\mathrm{~m} 44$ & 3.54 & 1.40 & 0.71 & 0.98 & $-19.38 * *$ \\
\hline $\mathrm{n} 21$ & 2.781 .59 & 0.82 & 0.98 & $-44.20 * *$ & $\mathrm{~m} 45$ & 3.58 & 1.36 & 0.69 & 0.98 & $-16.94 * *$ \\
\hline $\mathrm{n} 22$ & 3.161 .53 & 0.78 & 0.98 & $-30.86 * *$ & $\mathrm{~m} 47$ & 3.18 & 1.44 & 0.75 & 0.98 & $-21.39 * *$ \\
\hline $\mathrm{m} 23$ & 3.111 .49 & 0.79 & 0.98 & $-30.24 * *$ & $\mathrm{~m} 48$ & 2.94 & 1.49 & 0.80 & 0.98 & $-29.90 * *$ \\
\hline $\mathrm{m} 24$ & 3.071 .50 & 0.82 & 0.98 & $-38.72 * *$ & $\mathrm{~m} 49$ & 3.08 & 1.45 & 0.76 & 0.98 & $-25.94 * *$ \\
\hline $\mathrm{m} 25$ & 3.481 .38 & 0.72 & 0.98 & $-21.85^{* *}$ & $\mathrm{~m} 50$ & 3.24 & 1.47 & 0.69 & 0.98 & $-18.59 * *$ \\
\hline & & 9 & 3 & 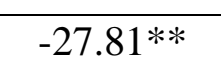 & & & & & & \\
\hline
\end{tabular}

\section{Cronbach Alpha: .98}

r: Madde toplam korelasyonu**<.01

${ }^{1}$ Madde çıkarıldığında Cronbach Alpha

\section{Sonuç ve Tartışma}

Yeni teknolojilerin günlük hayatta kullanımı hızla yayılmaktadır. Her alanda etkisini gösteren yeni teknolojiler artık eğitim kurumlarında da oldukça önemsenmekte olup, 21 . Yüzyılın öğretmen ve öğrenci nitelikleri de bu bağlamda şekillenmektedir. Özellikle Covid 19 pandemisi sürecind uzaktan eğitim faaliyetlerinin yoğunluk kazanması eğitim 
kurumlarının iki önemli paydaşı olan öğretmen ve öğrencilerin dijital yetkinliklerinin sorgulanmasını gerektirmiştir. Öğretim ortamlarının mimarı veya rehberi olarak nitelendirilebilecek öğretmenlerin eğitim fakültelerinde yetiştirilirken Web 2.0 araçlarını öğretim faaliyetlerinde kullanma becerisi kazanmaları önemli olup, bu çalışmada da geliştirilmeye çalışılan ölçek ile öğretmen adaylarının Web 2.0 araçlarını kullanım yetkinliği tespit edilecektir. Yapılan literatür taramasında (Tatlı, İpek-Akbulut ve Altınışık, 2016) öğretmen adaylarının Web 2.0 araçlarını derslere entegre bir şekilde kullanmasının onları mesleki anlamda yetkinleştirdiği bulgulanmıştır. Ayrıca literatürdeki ölçek geliştirme konuları (Bişirici, Kul, Aksu, Akaslan ve Çelik, 2017; Kuzu-Demir, ve Akbulut, 2017; Tekkurşun Demir, ve Mutlu Bozkurt, 2019; Çam, ve Uysal, 2017; Öztürk ve Horzum, 2011) ele alındığında yapılan bu çalışmayla benzer yönler bulunmakla birlikte, teknolojinin öğretmen eğitimindeki derslere entegre bir şekilde kullanımını kapsamlı ölçen bu çalışmanın alana zenginlik katacağı düşünülmüştür. Oluşturulan taslak form nihai şekli için uzman görüşüne sunulmuş olup, gelen dönütler çerçevesinde revize edilerek, öğretmen adaylarına uygulanmıştır.

Uygulamadan elde edilen veriler SPSS programında öncelikle güvenirlik ve geçerlik açısından analiz edilmiştir. Zira geliştirilmek istenen ölçeğin homojen bir yapı sergileyip sergilemediğinin tespitinde ölçeğin Cronbach Alfa katsayısına bakılması önem taşımaktadır. $\mathrm{Bu}$ çalışmada da ölçeğin güvenirlik katsayısı .98 olarak tespit edilmiştir. Ölçek çalışmalarında güvenirlik katsayısının en az .70 ve üzeri olması beklenmekte (Landis ve Koch, 1977; Robinson, Shaver ve Wrightsman, 1991) olup, Cronbach Alfa katsay1s1 0,80'in üzerinde tespit edilen ölçme araçlarının yüksek derecede güvenilir olduğu belirtilmiştir (Kalaycı 2009). Bu bağlamda geliştirilen bu ölçme aracının yüksek düzeyde güvenilir olduğu ve güvenirliği etkileyen hususlardan da uzak olduğu söylenebilir. Öyleki soruların hatalı yazımı, yetersiz soru sayısı, anlaşılmayan sorular, homojen olmayan sorular, uygulama sürecindeki ve puanlama aşamasındaki hatalar şeklindeki tüm faktörler bir ölçeğin güvenirliğini etkileyebilmektedir (Seçer, 2015). Çalışmanın geçerliğinin tespiti ve açımlayıcı faktör analizine uygunluğunu belirlemek için ise KMO ve Barlett Sphericity testleri gerçekleştirilmiş olup, KMO sonucu .97 bulunmuştur. Temelde 0 ile 1 arasında değerler alan KMO’nun değeri 1'e yaklaştıkça örneklemin yeterlilik derecesinin yükseldiği belirtilmektedir (Field, 2009). Field'e (2009) göre KMO eğer; 0.5 ile 0.7 arası ise orta, 0.7 ile 0.8 arası iyi, 0.8 ile 0.9 arası çok iyi ve 0.9 'un üzerindeki değerlerin ise örneklem yeterliliği açısından mükemmel olduğu belirtilmektedir. Faktör analizi için mükemmel 
uygunlukta olan veriler, döndürme işlemine tabi tutularak faktör yüklerine bakılmıştır. Bu işlemin sonucunda negatif veya faktör yük değerleri çok düşük olan maddeler ölçek diş1 bırakılmıştır. Zira Büyüköztürk’e (2011) göre, faktör yükleri .30'un altında olan maddeler ölçeğe alınmayabilir. Ölçekte istenen maddelerin yük değerlerinin 0,40'a eşit veya bu değerden büyük olması istenir. Çünkü düşük veya negatif faktör yük değerlerine sahip maddeler ölçek maddelerine olumlu görüş bildirenler ile bildirmeyenleri iyi ayırt etmemektedir. Bu ölçek çalışmasında da negatif ve düşük yük değerlerine sahip maddeler ölçek dışı bırakılmıştır.

Çalışmanın faktör sayısının belirlenmesinde Horn'un Paralel Analizi ve Catell'in yamaç eğim grafiğinden faydalanmıştır. Yamaç eğim testine göre grafikteki sıradanlığın aniden bozulduğu nokta, faktör sayılarının değerini vermektedir (Field, 2009). Bu çalışmada kullanılan yamaç eğim testine göre, grafikteki eğim ikinci faktörden sonra hızla düşme göstermiştir. $\mathrm{Bu}$ durum yamaç eğim grafiğinin iki faktörlü bir yapı sergilediği sonucunu vermektedir. Bu sonucun ayrıca Field'in (2009) öz değerin 1'den büyük olması kriterine de uyduğu tespit edilmiştir. Bu konuda literatüre bakıldığında genelde Horn'un Paralel Analizi (Horn, 1965) olarak bilinen tekniğin, bir ölçeğin boyut sayısının belirlenmesinde daha iyi sonuçlar gösterdiği belirtilmektedir (O’Connor, 2000; Piccone, 2009). Dolayısıyla paralel analizde öz değeri 1'den büyük (>1) boyutlar faktör olarak kabul edilmektedir. Bu durum ölçeğin faktör sayısının belirlenmesinde kullanılan Horn'un paralel analiz sonuçları ile Catell'in yamaç eğim testinden elde edilen sonuçların tutarlı olduğunu göstermektedir. Ancak açımlayıcı faktör analizi sonucu bulunan sonuçların doğrulayıcı faktör analizi ile de desteklenmesi gerekmektedir. Gizil değişkenler ile ilgili kuramların test edilmesine dayanan ve ileri düzey araştırmalarda kullanılan Doğrulayıcı faktör analizi (DFA), bu konularda güvenilir sonuçlar veren oldukça gelişmiş bir tekniktir (Tabachnick ve Fidell, 2001). Bu yönüyle DFA, AFA sonucu elde edilen faktör yapılarının test edilip doğrulanmasını sağlamış olur (Özdamar, 2016). Bu çalışmanın doğrulayıcı faktör analizi sonuçlarına göre; WAKYÖ’nün uyum indeksi değerleri sırasıyla; $\chi 2$ /df: 4.83, RMSEA: .098, CFI: .98 ve TLI: .98 olarak bulunmuştur. Elde edilen sonuçların kabul edilebilir aralık değerleri arasında olduğu görülmektedir. Sonuç olarak öğretmen adaylarının Web 2. 0 araçlarını kullanım yetkinliğinin tespitinde kullanılması amacıyla geliştirilen bu ölçme aracının 39 madde ve tek boyutlu yapısı ile güvenilir ve geçerli olduğu söylenebilir. 


\section{Kaynakça}

Alexander, B. (2006). Web 2.0: A new wave of innovation for teaching and learning? EDUCAUSE Review, 41(2), 32-44.

Bachman, L. F. (2004). Statistical analyses for language assessment book. Cambridge: Cambridge University.

Benzer, A. (2017). Dijital Çăgda Öğretim Teknolojileri ile Türkçe Ĕ̆itimi, Ankara: Yeni Anadolu Yayıncılık.

Bişirici, S., Kul, Ü., Aksu, Z., Akaslan, D. ve Çelik, S. (2017). Web 2. 0 hızlı içerik geliştirme öz-yeterlik inancı belirlemeye yönelik ölçek (W2ÖYİÖ) geliştirme çalışması, Eğitim Teknoloji Kuram ve Uygulama, 8 (1), 187-208.

Büyüköztürk, Ş. (2011). Sosyal Bilimler için Veri Analizi El Kitabı İstatistik, Araştırma Deseni SPSS Uygulamalarl ve Yorum, Ankara: Pegem Akademi Yayıncılı.

Chiou, Y. (2011). Perceived usefulness, perceive ease of use, computer attitude, and using experience of Web 2.0 applications as predictors of intent to use Web 2.0 by preservice teachers for teaching. Unpublished Doctoral Dissertation, Ohio University, Ohio.

Comrey, A. L., \& Lee, H. B. (1992). A First Course in Factor Analysis. (2th Edition), Hillsdale, Lawrence Erlbaum Associates Publishers, New Jersey.

Comrey, A. L., \& Lee, H. B. (1992). A First Course in Factor Analysis.Multivariate Behavioral Research, 1, 245-276.

Çam, E. ve Uysal, M . (2017). Mobil Uygulamaların Eğitsel Amaçlı Kullanımı: Bir Ölçek Geliştirme Çalışması. Uluslararası Türk Eğitim Bilimleri Dergisi, (9), 559-567.

Çelik, T. (2019). Bilinçli Sosyal Medya Kullanımı için Paydaşlarla El Ele. Ankara: Pegem Akademi.

Çokluk, Ö., Şekercioğlu, G. Ve Büyüköztürk, Ş., (2012). Sosyal Bilimler İçin Çok Değişkenli İstatistik SPSS ve LISREL Uygulamalarl, Ankara: Pegem Akademi Yayınc1lık.

Dellos, R. (2015). Kahoot! A digital game resource for learning. International Journal of Instructional Technology and Distance Learning, 12(4), 49-52. 
Elmahdi, I., Hattami, A., \& Fawzi, H. (2018). Using technology for formative assessment to improve students' learning. The Turkish Online Journal of Educational Technology (TOJET), 17(2), 182-188.

Elmas, R., \& Geban, O. (2012). Web 2.0 tools for 21st century teachers. International Online Journal of Educational Sciences, 4(1), 243-254.

Elswick, J. \& Lennex, L. (2017). Technology use in secondary chemistry and physics classrooms in Kentucky. Society for Information Technology and Teacher Education International Conference, TX, United States Association for the Advancement of Computing in Education (AACE), Chesapeake, VA.

Eşgi, N. ve Kocadağ Ünver, T. (2018). Bilişim Teknolojileri, Öğretim Teknolojileri, Materyal Geliştirme Iç̧in Web 2. 0 Araçları, Ankara: Nobel Akademi Yayıncılık.

Field, A. (2009). Discovering statistics using SPSS (3. bask1). London: Sage

Geçgel, H., Kana, F. \& Eren, D. (2020). Türkçe Eğitiminde Dijital Yetkinlik Kavramının Farklı Değişkenler Açısından İncelenmesi. Ana Dili Eğitimi Dergisi, 8(3), 886-904.

Graham, K. (2015). TechMatters: Getting into Kahoot!(s): Exploring a game-based learning system to enhance student learning. LOEX Quarterly, 42(3), 6-7.

Gündüz, Ş. (2007). Öğretmen Eğitiminde Bilgi ve İletişim Teknolojileri Planlama Rehberi, H. Ferhan Odabaşı (Çeviri Ed.), Bilgive Illetişim Teknolojileri ve Öğretmen Ĕgitimi: Küresel Băglam ve Yapı (s. 5-22), Ankara: Nobel Akademi Yayıncılık.

Gününç, S. (2017). Eğitimde Teknoloji Entegrasyonunun Kuramsal Temelleri, Ankara: Anı Yayıncilik.

Hartshorne, R., \& Ajjan, H. (2009). Examining student decisions to adopt Web 2.0 technologies: theory and empirical tests. Journal of Computing in Higher Education, 21(2).

Horn, J. L. (1965). A rationale and test for the number of factors in factor analysis. Psychometrika, 30(2), 179-185.

Horzum, M. B. \& Aydemir, Z. (2014). Web 2.0 Tools and Educational Usage Self-Efficacy: A Scale Development Study, Procedia - Social and Behavioral Sciences 116 (1) 453 -458 . 
Horzum, M. B. (2010). Oğretmenlerin web 2.0 araclarından haberdarlığı, kullanım sıklıkları ve amaclarının ceşitli değişkenler acısından incelenmesi. Uluslararası İnsan Bilimleri Dergisi, 7(1), 603-634.

Hung, H., \& Yuen, S. (2010). Educational use of social networking technology in higher education. Teaching in Higher Education, 15(6), 703-714.

Hurlburt, S. (2008). Defining tools for a new learning space: Writing and reading class blogs. MERLOT Journal of Online Learning and Teaching, 4(2),182-189.

Kalaycı, Ş. (2006), SPSS Uygulamalı Çok Değişkenli İstatistik Teknikleri. (Ed.: Ş.Kalaycı). 2. Bask1. Ankara: Asil Yayıncılık.

Kass, R. A. and Tinsley, H. E. A. (1979). Factor analysis. Journal of Leisure Research, 11, $120-138$.

Kazanc1, A.ve Dönmez, F. İ. (2013). OKUL 2.0 Eğitimde Sosyal Medya ve Mobil Uygulamalar, Ankara: Anı Yayıncılık.

Kline, R. B. (2011). Principles and practice of structural equation modeling (3. bask1). New York, NY: Guilford.

Kutlu Demir, Ö. (2018). 21. yüzyılda öğrenme: Web 2.0 araçlarının yetişkin Türk dil sınıflarına entegrasyonu. Yayımlanmış Doktora Tezi. Çağ Üniversitesi, Mersin.

Kuzu-Demir, E.B. ve Akbulut, Y. (2017). Çevrimiçi sosyal ağların öğretim amaçlı kabul ve kullanımı ölçeğinin geliştirilmesi. Türk Bilgisayar ve Matematik Ĕgitimi Dergisi, $8(1), 52-82$.

Landis, J. R. ve Koch, G. G. (1977). The measurement of observer agreement for categorical data. Biometrics, 33, 159-174

Laru, J., Naykki, P., \& Jarvela, S. (2012). Supporting small-group learning using multiple Web 2.0 tools: A Case study in the higher education context. Internet and Higher Education, 15, 29-38.

McLoughlin, C. \& Lee, M. J. W. (2007). Social software and participatory learning: Pedagogical choices with technology affordances in the Web 2.0 era. 24th Annual Conference of the Australasian Society for Computers in Learning in Tertiary Education, Singapore, Singapur Kongresine sunulmuş bildiri. 
O'Connor, B. P. (2000). SPSS and SAS programs for determining the number of components using parallel analysis and Velicer's MAP test. Behavior Research Methods, Instruments, \& Computers, 32(3), 396-402.

O'Reilly T. (2007). What is web 2.0: design patterns and business models for the next generation of software. Communications \& Strategies, 65, 17-37.

Orhan Göksün, D. ve Aşkım Kurt, A., (2018). Öğretim teknolojilerinin temelleri, Kurt, A. A., (Ed.), 21. Yüzyll Öğrenci ve Öğretmen Becerileri (s. 95-114). Ankara: Nobel Akademi Yayıncılık.

Önal, N. (2018). Etkinlik örnekleriyle zenginleştirilmiş eğitimde teknoloji uygulamaları, Önal, N. (Ed.), Öğretimde Kullanılabilecek Teknoloji Destekli Uygulamalar, (s.213). Ankara: Pegem Akademi.

Özdamar, K. (2016). Eğitim, săghlk ve davranış bilimlerinde ölçek ve test geliştirme yapısal eşitlik modellemesi. Eskişehir: Nisan Yayıncılık.

Öztürk, E. ve Horzum, M. B. (2011). Teknolojik pedagojik içerik bilgisi ölçeği’nin Türkçeye uyarlaması. Ahi Evran Üniversitesi Eğitim Fakültesi Dergisi 12(3), 255278.

Pohlmann, J. T. (2004), Use and Interpretation of factor analysis in the journal of educational research: 1992-2002. The Journal of Educational Research, 98(1), 14-23

Rich, M. (2008). Millennial students and technology choices for information searching. Electronic Journal of Business Research Methods, 6(1), 73-76.

Seçer, İ. (2015). Pisikolojik Test Geliştirme ve Uyarlama Süreci SPSS ve Lisrel Uygulamaları, Anı yayınc1lık, Ankara.

Sümer, N. (2000), Yapısal Eşitlik Modelleri. İstanbul: Türk Psikoloji Yayınları

Şahin, Y. L. (2013). Teknopedagojik Eğitime Dayalı Öğretim Teknolojileri ve Materyal Tasarımı, Kabakçı Yurdakul, I. (Ed.), Teknopedagojik Eğitimde Web 2. 0 araçları (s. 163-192), Ankara: Anı Yayıncılık.

Tabachnıck, B. G. ve Fidell, L. S. (2007), Using Multivariate Statistics (5. Ed.). Boston: Allyn And Bacon.

Tabachnick, B.G. ve Fidell, L.S. (2001). Çok değişkenli istatistiklerin kullanılması (4. bask1). Needham, MA: Allyn ve Bacon. 
Tatlı, Z. (2017). Kavram Öğretiminde Web 2. 0, Tatlı, Z. (Ed.), Pixton, (s. 262-273). Ankara: Pegem Akademi.

Tatlı, Z., İpek-Akbulut, H. ve Altınışık, D. (2016). Öğretmen adaylarının teknolojik pedagojik alan bilgisi özgüvenlerine web 2.0 araçlarının etkisi. Türk Bilgisayar ve Matematik Eğitimi Dergisi, 7(3), 659-678.

Tavşancıl, E. (2014). Tutumların ölçülmesi ve SPSS ile veri analizi. Ankara: Nobel.

Tekkurşun Demir, G. ve Mutlu Bozkurt, T. (2019) Dijital Oyun Oynama Tutumu Ölçeği (DOOTÖ): Geçerlik ve Güvenirlik Çalışması, Sportif Bakış: Spor ve Ĕ̆itim Bilimleri Dergisi, 6 (1), 1-18.

Telli Yamamoto G. ve Karamanlı Şekeroğlu, Ö. (2014). Sosyal Medya ve Blog. İstanbul: Kriter Yayınevi.

Thompson, J. (2007). Is education 1.0 ready for web 2.0 students?. Innovate: Journal of OnlineEducation, 3(4), No: 5.

Tsarev, R. Y. (2017). Application of Kahoot! in education gamification. International Journal of Advanced Studies, 7(1), 9-17.

Vaughan, N. (2010). Student engagement and Web 2.0: What's the connection? Education Canada, 50(2), 52-55.

Wang, A. I., \& Lieberoth, A. (2016). The effect of points and audio on concentration, engagement, enjoyment, learning, motivation, and classroom dynamics using Kahoot!. In European Conference on Games Based Learning (p. 738). Academic Conferences International Limited.

Worthıngton, R. L., ve Whittaker, T. A. (2006), Scale development research: A content analysis and recommendations for best practices. The Counseling Psychologist, 34(6), 806-838.

Zarzycka-Piskorz, E. (2016). Kahoot it or not? Can games be motivating in learning grammar?. Teaching English with Technology, 16(3), 17-36. 


\section{Ekler (Varsa)}

Ek-1: Web2.0 Araçları Kullanım Yetkinliği Ölçeği (WAKYÖ)

\begin{tabular}{|c|c|c|c|c|c|c|}
\hline & & 1 & 2 & 3 & 4 & 5 \\
\hline Yeni & Web2.0 Araçları Kullanım Yetkinliği Ölçeği & & & & & \\
\hline Madde & (WAKYÖ) & & ฮี & $\dddot{\pi}$ & $\frac{\pi}{x}$ & $\tilde{\Xi}$ \\
\hline No & & & $\begin{array}{l}\overline{\tilde{z}} \\
\bar{Z}\end{array}$ & $\underset{\pi}{\pi}$ & $\overline{\bar{a}}$ & $\dot{\bar{\theta}}$ \\
\hline 1 & $\begin{array}{l}\text { 5. Web 2. } 0 \text { araçları ile zamandan ve mekândan } \\
\text { bağımsız öğrenme ortamları tasarlayabilirim. (Örneğin } \\
\text { Edmodo, Beyaz pano, Google Classroom... gibi) }\end{array}$ & & & & & \\
\hline 2 & $\begin{array}{l}\text { 6. Web 2. } 0 \text { araçları ile etkili sunumlar hazırlayabilirim. } \\
\text { (Prezi, Powtoon, Buncee, Emaze... gibi) }\end{array}$ & & & & & \\
\hline 3 & $\begin{array}{l}\text { 7. Web } 2.0 \text { araçları ile bir konudaki bilgi ve kavramları } \\
\text { zihin haritası şeklinde sunabilirim. (Wisemapping, } \\
\text { Pooplet, SpiderScribe,Gocongr...gibi) }\end{array}$ & & & & & \\
\hline 4 & $\begin{array}{l}\text { 8. Web 2. } 0 \text { araçları ile animasyon etkinlikleri } \\
\text { hazırlayabilirim. (Vyond, Voki...gibi) }\end{array}$ & & & & & \\
\hline 5 & $\begin{array}{l}\text { 10. Web } 2.0 \text { araçları ile dijital panolar hazırlayabilirim. } \\
\text { (Padlet, Bendspace, Lino ti...gibi) }\end{array}$ & & & & & \\
\hline 6 & $\begin{array}{l}\text { 11. Web } 2.0 \text { araçları ile poster hazırlayabilirim. (Word } \\
\text { art, Sketch toy...gibi) }\end{array}$ & & & & & \\
\hline 7 & $\begin{array}{l}\text { 12. Web 2. } 0 \text { araçları ile karikatür hazırlayabilirim. } \\
\text { (Make Beliefs Comix, Toondoo...gibi) }\end{array}$ & & & & & \\
\hline 8 & $\begin{array}{l}\text { 13. Web 2. } 0 \text { araçları ile dijital hikâye oluşturabilirim. } \\
\text { (Storyjumper, Storybird, Pixton...gibi) }\end{array}$ & & & & & \\
\hline 9 & $\begin{array}{l}\text { 14. Web 2. } 0 \text { araçları ile sanal yazarlık yapabilirim. } \\
\text { (Wattpad, Blogger...gibi) }\end{array}$ & & & & & \\
\hline 10 & $\begin{array}{l}\text { 15. Web 2. } 0 \text { araçları ile yazdığım hikayelere ses } \\
\text { ekleyebilirim. (Storyjumper.. gibi) }\end{array}$ & & & & & \\
\hline 11 & $\begin{array}{l}\text { 17. Web } 2.0 \text { araçları ile blog oluşturabilirim. (Blogger, } \\
\text { Tumblr... gibi) }\end{array}$ & & & & & \\
\hline 12 & $\begin{array}{l}\text { 18. Web 2. } 0 \text { araçları ile dijital test hazırlayabilirim. } \\
\text { (Kahoot, Plickers, Socrative... gibi) }\end{array}$ & & & & & \\
\hline 13 & $\begin{array}{l}\text { 19. Web 2. } 0 \text { araçları ile bulmaca oluşturabilirim. } \\
\text { (Mentimeter, Flipquiz... gibi) }\end{array}$ & & & & & \\
\hline 14 & $\begin{array}{l}\text { 20. Web 2. } 0 \text { araçları ile yapboz oluşturabilirim. } \\
\text { (Paz1llmaker, LearningApss...gibi) }\end{array}$ & & & & & \\
\hline 15 & $\begin{array}{l}\text { 21. Web 2. } 0 \text { araçları ile alanımda eğitsel oyun } \\
\text { tasarlayabilirim. (Kahoot, Plickers, Socrati, Thinklink, } \\
\text { LearningApss...gibi) }\end{array}$ & & & & & \\
\hline
\end{tabular}




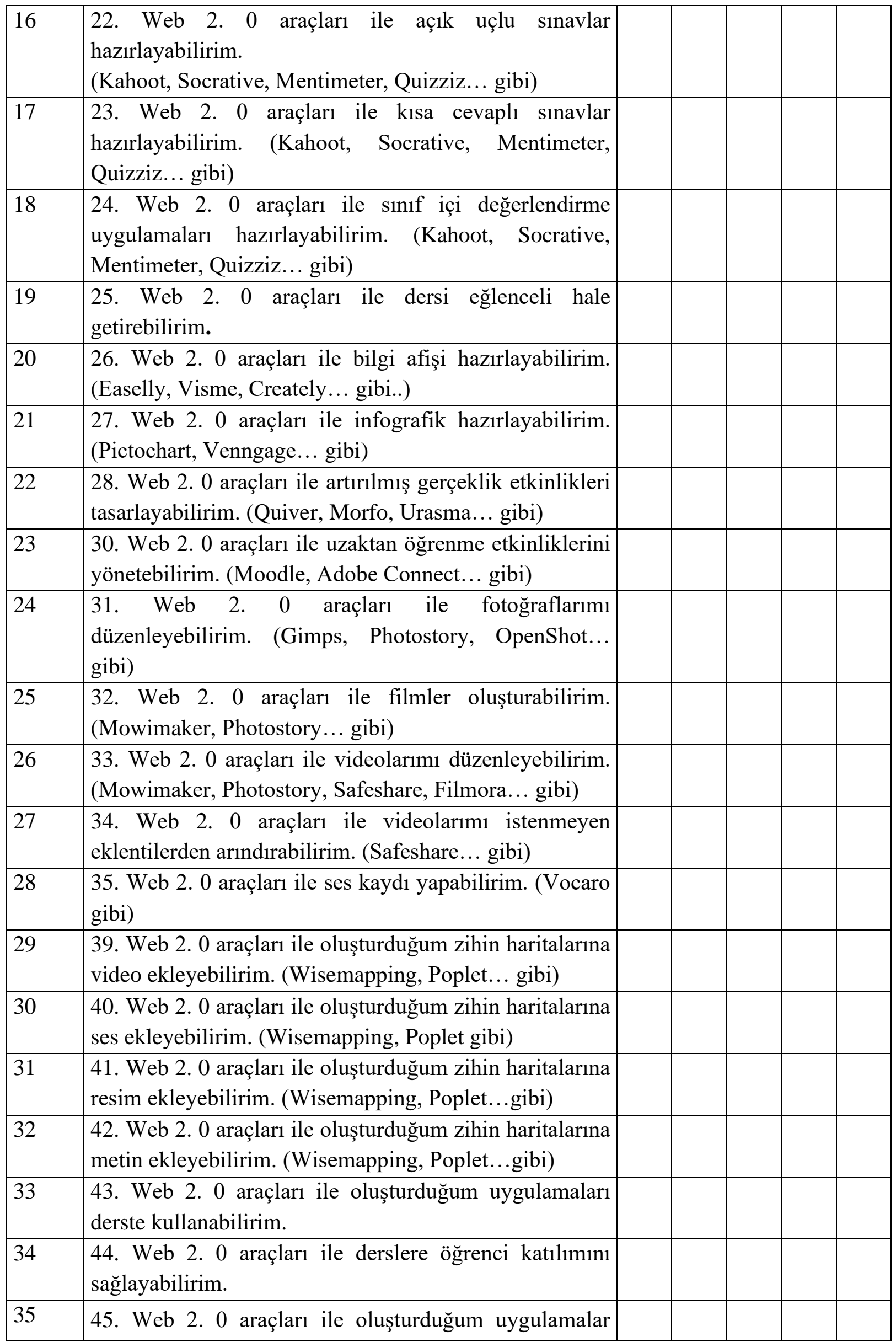




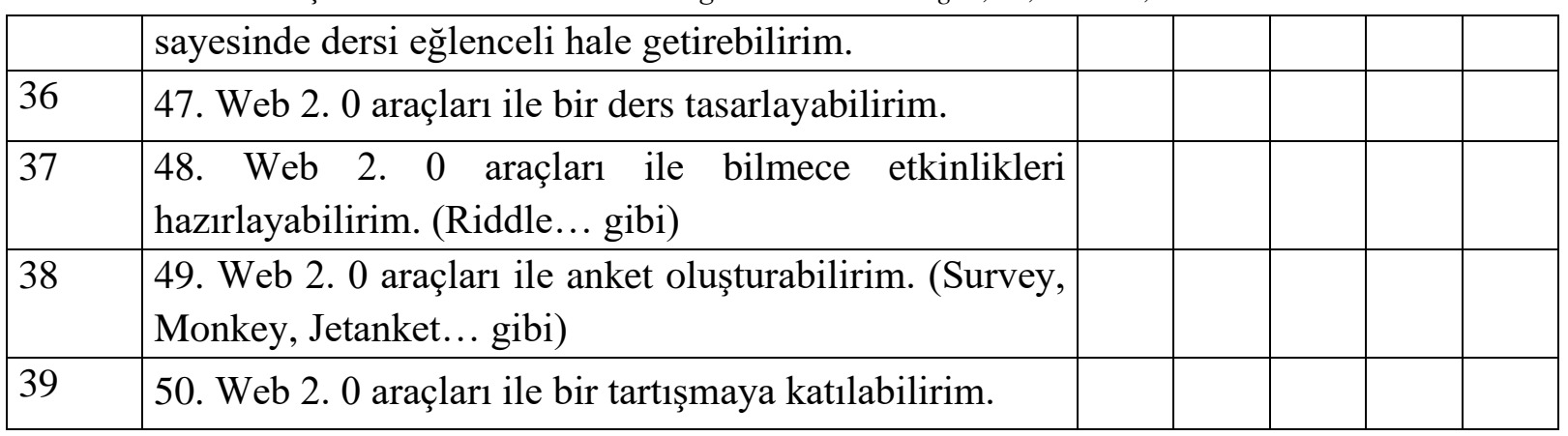

